\title{
Vjerski prijelazi s pravoslavne na rimokatoličku i grkokatoličku vjeroispovijest na području Čazmanskog arhiđakonata između 1941. i 1945.
}

DOI: https://doi.org/10.11567/met.33.3.2 UDK: 322(497.5-3Moslavina)"1941/1945"

Prethodno priopćenje

Primljeno: 19.04.2017.

Prihvaćeno: 19.02.2018.

\section{Filip Škiljan}

Institut za migracije i narodnosti, Zagreb

filip.skiljan@imin.hr

\section{SAŽETAK}

U tekstu se donose podaci o vjerskim prijelazima na području Čazmanskog arhiđakonata, koji je obuhvaćao najveći dio Moslavine i manji dio Bilogore. Na tome je području do Drugoga svjetskog rata živjelo oko 17.000 pravoslavnih Srba, koji su činili približno $14 \%$ sveukupnog stanovništva. Nakon uspostave NDH ustaše su počeli provoditi teror nad srpskim stanovništvom. Istaknutiji Srbi otpremani su u zatvore i logore, a dio onih koji su uhićeni tijekom travnja i svibnja 1941. stradao je u logoru Jadovno na Velebitu. Tijekom srpnja, kolovoza i rujna 1941. na području Moslavine i Bilogore provedena su uhićenja i organizirana prisilna iseljavanja Srba preko logora Bjelovar, Caprag i Požega u Srbiju. Istovremeno s tim događajima, u proljeće i ljeto 1941. počeli su i vjerski prijelazi s pravoslavne na rimokatoličku vjeroispovijest. U tekstu se pokušavaju na temelju izvorne arhivske građe iz Nadbiskupijskog arhiva u Zagrebu i Hrvatskoga državnog arhiva donijeti zaključci o broju osoba koje su podnijele molbu za prijelaz s pravoslavne na rimokatoličku vjeroispovijest. Na temelju poimeničnih popisa dolazi se do zaključka da je najmanje 3271 osoba tražila prijelaz s pravoslavne na rimokatoličku vjeroispovijest, s time da je najveći broj njih prijelaz zatražio od Nadbiskupskoga duhovnog stola na početku 1942. Analiziraju se i pojedinačni prijelazi, odnosno razlozi zbog kojih su pojedinci prelazili s pravoslavne na rimokatoličku vjeroispovijest, s naglaskom na masovnim vjerskim prijelazima poput onih koji su zabilježeni i za koje nam postoje popisi prekrštenih, kao onaj u Kaniškoj Ivi i selima oko Kaniške Ive. Autor se bavi i masovnim vjerskim prijelazima za koje nemamo poimenično popisane prijelaznike, kao na primjer onaj u novoosnovanoj prijelazničkoj župi Mikleuška. Kao posebni aspekt promatraju se i prijelazi na grkokatoličku vjeroispovijest (Veliki Zdenci i okolica Čazme) te razlozi zbog kojih državne vlasti nisu željele da pravoslavni vjernici prelaze na grkokatoličku vjeroispovijest. Na temelju izvještaja pojedinih župnika zaključuje se da prijelazi na rimokatoličku vjeroispovijest u većem broju slučajeva nisu bili iskreni, odnosno da su Srbi u većini slučajeva prelazili na rimokatoličku vjeroispovijest isključivo zbog očuvanja vlastite egzistencije. Osnutkom Hrvatske pravoslavne crkve u prvoj polovini 1942. pravoslavni vjernici uglavnom su prestali prelaziti na rimokatoličku vjeroispovijest.

KLJUČNE RIJEČI: vjerski prijelazi, Srbi, Drugi svjetski rat, Moslavina, Čazmanski arhiđakonat 


\section{UVOD}

Korijeni mnogih aspekata odnosa Rimokatoličke crkve spram Nezavisne Države Hrvatske (NDH) sežu duboko u prošlost, ali u bližoj prošlosti, u prvoj polovini 20. stoljeća, kad su odnosi Svete Stolice s državama bili uređivani posebnim, sveobuhvatnim ugovorima, konkordatima, okolnost koja je utjecala na vjersku konstelaciju i političke prilike u Kraljevini Jugoslaviji pred Drugi svjetski rat tiče se upravo jednoga konkordata, odnosno njegova nepostojanja. Sveta Stolica nije ni formalno priznala Nezavisnu Državu Hrvatsku i nije potpisala nikakav međunarodnopravni ugovor s NDH. No odnos Svete Stolice prema NDH bio je obilježen, između ostaloga, i činjenicom da Kraljevina Jugoslavija sa Svetom Stolicom nije imala valjan sveobuhvatni međunarodnopravni ugovor (tzv. konkordat). ${ }^{1}$

Pregovori oko konkordata Vatikana i Kraljevine Jugoslavije otpočeli su ranih dvadesetih godina dvadesetog stoljeća i potrajali više od desetljeća, da bi se 1935. postigla suglasnost oko svih detalja te se formirani ugovor (koji Stojadinovićeva vlada potpisuje 1937.) poslao u Skupštinu i Senat na usvajanje. No tada zbog ogorčenog protivljenja Srpske pravoslavne crkve (SPC) konkordatu nastaje duboka politička kriza, uz krizu oko atentata u Skupštini možda i najveća između dva rata, i proces ratifikacije konkordata se obustavlja. Povlašteni položaj Srpske pravoslavne crkve u višekonfesionalnoj Kraljevini ogledao se, između ostaloga, i u neravnomjernoj podjeli proračunskog novca za crkve i vjerske zajednice. SPC je naime dobivao čak dvije trećine iznosa namjenskih državnih subvencija. Povlaštenim položajem Srpske pravoslavne crkve u Kraljevini otvarao se prostor i pravoslavnom prozelitizmu i teritorijalnoj ekspanziji SPC-a na prostor gdje otprije nije imao korijena. Gradio se niz crkava i osnivao niz parohija na područjima gdje pravoslavlje nije bilo rašireno (npr. Vis i Sušak), a i više je vjerskih prijelaza bilo s rimokatoličke na pravoslavnu vjeroispovijest nego obratno. Prema pismu nadbiskupa Alojzija Stepinca papi, posrijedi je bilo oko 200.000 takvih prijelaznika. Dio je konvertirao zbog obiteljskih razloga (npr. zbog ponovnog sklapanja crkvenog braka, vjerski mješovitih brakova itd.), dio je tako postupio iskreno, na krilima integralnog jugoslavenstva (u Dalmaciji je to ponekad bila gesta protiv talijanaštva), ali bilo je katolika koji su prelazili na pravoslavlje i iz koristoljubivosti, samo radi poboljšanja svog položaja u društvu (naročito među državnim službenicima). Hrvatski katolički kler, i Stepinac osobno, taj je broj doživljavao vrlo dramatično i više puta se njime implicite koristio kao argumentom za pravoslavni prozelitizam. Neposredno nakon proglašenja NDH (10. travnja) nadbiskup Stepinac posjećuje Slavka Kvaternika (12. travnja), a ubrzo i dr. Antu Pavelića (16. travnja, dan nakon njegova dolaska u Zagreb). Tim nadbiskupovim posjetima, kao i njegovom poslanicom svećenicima u NDH od 28. travnja 1941., u kojoj izražava zadovoljstvo osnivanjem NDH i poziva svećenstvo na »uzvišeni rad oko čuvanja i unapređenja hrvatske države " (isto su učinili i splitsko-dalmatinski, krčki i senjski biskup), visoki katolički kler jednoj revolucionarno proglašenoj novoj državi na teritoriju međunarodno priznate Kraljevine Jugoslavije (koja još nije kapitulirala; to je učinila 17. travnja) izravno i javno daje legitimitet (daje legitimaciju kako jednom deklariranom ideološkom konstruktu tako i državno-pravnom okviru kao režimskom instrumentu). Legalitet se pak »vukao« iz formalne primopredaje banovinske uprave 10. travnja 1941. i produljenja rada izabranog saziva Sabora.

U okviru svoje ideologije »konačnog rješenja srpskog pitanja« ustaše su Srpsku pravoslavnu crkvu smatrali nositeljem nacionalnog identiteta Srba u Hrvatskoj, pa su se pravoslavni svećenici našli prvi na udaru ustaških vlasti. Pravoslavnim je vjernicima pak, 
U ovom članku naglasak je na vjerskim prijelazima s pravoslavne na rimokatoličku i grkokatoličku vjeroispovijest za Drugoga svjetskog rata na području Čazmanskog arhiđakonata, koji pokriva najveći dio Moslavine. ${ }^{2}$ Ta nam je zona bila posebno zanimljiva zbog broja vjerskih prijelaza srpskoga pravoslavnog stanovništva koje je živjelo na tome području i zbog činjenice da je to bilo uglavnom mirno područje gdje većih ratnih operacija nije bilo do $1944 .^{3}$

$\mathrm{O}$ broju prijelaznika s pravoslavne na rimokatoličku vjeroispovijest $\mathrm{u}$ vrijeme postojanja NDH raspravlja se već desetljećima. Najranija je kumulativna kvantifikacija konverzija pravoslavnih u katolike u NDH u jednom izvještaju papi Piju XII. iz 1943. koji je napisao nadbiskup Alojzije Stepinac. Iako se još uvijek spekulira o ukupnom broju prijelaznika s pravoslavne na rimokatoličku vjeroispovijest u NDH, ipak se danas većina kontroverzi uglavnom tiče karaktera i etičnosti te doktrinarne dosljednosti i političke oportunosti samog čina konverzije.

s ciljem odnarođivanja i asimilacije, bila planirana konverzija - trebalo ih je prevesti na rimokatoličku, odnosno na grkokatoličku vjeroispovijest, što bi prethodilo njihovu pohrvaćenju (Vlada NDH donosi odluku da se prijelaznici moraju nacionalno izjašnjavati kao Hrvati). Stoga je donesen niz Zakonskih odredbi i okružnica koji omogućuju te prijelaze. Ovi svi podaci već su izneseni u tekstovima: Tomasevich, 2010; Požar, 1996; Krišto, 1998, 2001; Đurić, 1991; Jelić-Butić, 1978; Škiljan, 2014: 135-173, 2015a: 97-107, 2015b: 101-122, 2016a: 168-179, 2016b: 185-202, 2016c: 117-135, 2016d: 295-314, 2017a: 223-251, 2017b: 127-145, 2017c: 173-195. Djelo Joze Tomasevicha (2010) donosi vrlo zanimljive i vrijedne informacije o okolnostima dobivanja podataka o vjerskim prijelazima nakon Drugoga svjetskog rata. Djelo Petra Požara (1996) donosi informacije o osnivanju, položaju i djelovanju Hrvatske pravoslavne crkve u NDH. Djelo Fikrete Jelić-Butić (1978) donosi nam osnovne podatke o vjerskim prijelazima, a rad Veljka Đ. Đurića (1991) donosi niz dokumenata i arhivske građe vezanih uz vjerske prijelaze. Posebno su vrijedna djela Jure Krište $(1998,2001)$, koji u svojim člancima i knjigama donosi podrobne podatke o tome kakva je bila uloga države, a kakva uloga Rimokatoličke crkve prilikom podnošenja molbi za vjerski prijelaz, odobravanja molbe i konačno obavljanja samog čina vjerskog prijelaza. Njegovi su radovi pisani na temelju izvorne arhivske građe.

2 Čazmanski arhiđakonat obuhvaća Čazmanski dekanat, koji se sastoji od župa Čazma, Dapci, Draganec, Ivanska, Miklouš, Samarica i Štefanje, Garešnički dekanat, koji obuhvaća župe Garešnica, Grubišno Polje, Hercegovac, Ivanovo Selo, Kaniška Iva, Ladislav, Stara Ploščica, Tomašica i Velika Trnovitica, Ivanički dekanat, koji obuhvaća župe Ivanić-grad, Kloštar Ivanić, Dubrovčak Lijevi, Lupoglav, Oborovo, Posavski Bregi i Savski Nart, te Moslavački dekanat, koji obuhvaća župe Gornja Jelenska, Križ, Kutina, Ludina, Osekovo, Popovača, Voloder i Vrtlinska (Draganović, 1975: 94-98).

3 Prva grupa Moslavačkoga partizanskog odreda formirana je 5. kolovoza 1941. kod sela Gornja Šušnjara. No ta je grupa vrlo brzo razbijena te je brojila tek jedanaest pripadnika. U studenom 1941. formira se nova grupa, tzv. Istočni dio Moslavačkoga partizanskog odreda, a 14. prosinca 1941. i Zapadni dio Moslavačkoga partizanskog odreda. Prva akcija bila je kod sela Prečec 23. prosinca 1941. Dana 26. siječnja 1942. odred je brojio pedeset boraca. Veća akcija u prvoj polovini rata u kojoj je odred sudjelovao bila je Bitka na Gojlu 6. rujna 1942. Moslavački partizanski odred izveo je tijekom rata više akcija na moslavačkom području. (Vidi više o tome u: Karanović, 1981). 
Srpsko je stanovništvo na području Čazmanskog arhiđakonata činilo manjinu. Prema popisu iz 1931., Srbi su na području kotara Garešnice činili 19,8\% stanovništva (6137 od 30.971 stanovnika), na području kotara Kutine 6,5\% stanovnika (1810 od 28.041 stanovnika), a na području kotara Čazme 4,8\% (1843 od 38.044 stanovnika). Čazmanski arhiđakonat obuhvaćao je i župu Grubišno Polje koja se nalazi u regiji Bilogore, a koja je u vrijeme popisa 1931. imala znatno veći udio srpskoga pravoslavnog stanovništva nego što je udio Srba bio u broju stanovnika Moslavine. Na području kotara Grubišnog Polja, koji obuhvaća općine Ivanovo Selo, Grubišno Polje i Veliki Grđevac, bilo je prema popisu iz 1931. godine 11.211 pravoslavnih (Srba) i 12.776 rimokatolika (uglavnom Hrvata i Čeha) od ukupno 24.179 stanovni$\mathrm{ka}^{4}$

Dakle područje Čazmanskog arhiđakonata obuhvaća najveći dio današnje Moslavine, odnosno gotovo čitavo kutinsko područje (osim Međurića), ivanićgradsko područje, garešničko područje i najveći dio čazmanskog područja te područje Grubišnog Polja. Izvan granica toga arhiđakonata nalazi se područje južno od Vrbovca (Dubrava i okolina) koje geografski također pripada Moslavini i koje je u međuratnom razdoblju spadalo pod kotar Čazmu. Početkom Drugoga svjetskog rata na području Čazmanskog arhiđakonata živjelo je oko 17.000 Srba (oko 14\% ukupnog broja stanovnika).

Budući da se ovaj rad temelji na poimeničnim popisima osoba koje su zatražile vjerski prijelaz s pravoslavne na rimokatoličku vjeroispovijest, evidentiranih $\mathrm{u}$ dokumentima pohranjenim u Hrvatskome državnom arhivu i Nadbiskupijskom arhivu u Zagrebu, gdje je župa osnovna klasifikacijska razina, ravnat ćemo se prema tadašnjoj župskoj podjeli. Cilj je rada pokazati koliko je bilo vjerskih prijelaza s pravoslavne na rimokatoličku i grkokatoličku vjeroispovijest, odnosno koliko je ljudi podnijelo molbe za vjerske prijelaze s pravoslavne na rimokatoličku i grkokatoličku vjeroispovijest na području Čazmanskog arhiđakonata, koje su bile okolnosti tih prijelaza, odnosno na koji su način prijelaznici prelazili na rimokatoličku i grkokatoličku vjeroispovijest i kako ih je primalo rimokatoličko i grkokatoličko svećenstvo. Jedan je od ciljeva rada pokazati na koji su način Rimokatolička crkva i Grkokatolička crkva preuzimale objekte Srpske pravoslavne crkve.

Za potrebe ovoga rada pregledani su fondovi Odjel bogoštovlja Ministarstva pravosuđa i bogoštovlja NDH u Hrvatskom državnom arhivu te

4 Vidi u: Definitioni rezultati popisa stanovništva od 31. marta 1931. godine, knjiga II, Prisutno stanovništvo po veroispovesti (Kraljevina Jugoslavija, Opšta državna statistika, 1938). Općina Veliki Grđevac nalazi se u Bjelovarskom arhiđakonatu, dakle izvan našeg područja istraživanja. 
fond Nadbiskupski duhovni stol u Nadbiskupijskom arhivu u Zagrebu. Pribavljen je i Dnevnik S. D.-a, koji je kao izravni svjedok tih događaja zapisao svoja sjećanja. Zaključci su doneseni na temelju izvornih dokumenata i poimeničnih popisa prijelaznika, odnosno podnositelja molbi za prijelaz, koji su pronađeni u navedenoj građi, a odnose se na Čazmanski arhiđakonat.

\section{USTAŠKI TEROR NAD SRBIMA U MOSLAVINI 1941.}

Vrlo brzo nakon uspostave NDH ustaše su počinili prvi masovni zločin u neposrednom susjedstvu Moslavine. Na području Gudovca 28. travnja 1941. ubijeno je 202 ljudi, uglavnom Srba. Taj zločin svakako je bio poznat stanovnicima Moslavine jer je bilo rodbinskih veza Gudovčana sa Srbima iz Moslavine. Gotovo istovremeno s velikim stradanjem Srba u Gudovcu kraj Bjelovara, 27. travnja 1941., u nedalekom Grubišnom Polju odvijalo se masovno hapšenje stanovnika srpske nacionalnosti, čija sudbina u konačnici neće biti drugačija od sudbine gudovačkih žrtava. Od 574 Grubišnopoljca upućena u logor Danicu (što ne znači da su svi Grubišnopoljci stigli prvim transportom 28. travnja 1941.) 560 ih je izgubilo živote (Dizdar, 2002: 388). Svi uhićeni bili su Srbi. Prema popisu žrtava, u Jadovnom i na Pagu stradalo je najmanje 557 Srba iz Grubišnog Polja i okolice, uhićenih većinom krajem travnja 1941. (Zatezalo, 2009: 554-570). ${ }^{5}$ I iz garešničkoga kotara bilo je odvođenja u Danicu, a zatim u Jadovno, ali manje. Uhićenja su provedena u svibnju i u drugoj polovini srpnja 1941., u najvećoj mjeri na području općine Vukovje. Uhićivani su istaknuti i bogatiji Srbi, a devetnaest ih je stradalo u Jadovnom. S područja kutinskoga kotara u Jadovnom je ubijeno pet Srba, a s ivanićkog područja jedan (Zatezalo, 2009: 455-457, 598).

Sredinom srpnja 1941. u garešničkom i grubišnopoljskom kotaru uhićeni su svi pravoslavni svećenici s obiteljima i deportirani u logor Caprag, odakle je većina njih prisilno iseljena u Srbiju.

Početkom kolovoza počeli su masovno uhićivanje Srba na području kotara Grubišnog Polja i njihovo organizirano deportiranje u sabirne logore Caprag, Požega i Bjelovar radi prisilnog iseljavanja u Srbiju. Samo u kolovozu 1941. s područja kotara Grubišnog Polja uhićeno je i u Srbiju deportirano 2717 osoba. S područja kotara Čazme organizirano je prisilno iseljeno 166 osoba, a s područja kotara Kutina 46. Iz garešničkoga kotara trebala je biti

Prema popisu koji je donio dr. Đuro Zatezalo u knjizi Jadovno - kompleks ustaških logora, s područja kotara Grubišnog Polja u Jadovnom i na otoku Pagu ubijeno je 537 osoba. On donosi i poimenični popis žrtava. 
iseljena najmanje 531 osoba, ali su iseljeni samo pravoslavni svećenici i njihove obitelji, njih devet (Škiljan, 2012: 149-169, 2015c: 159-160).

\section{PREVJERAVANJE PRAVOSLAVNIH VJERNIKA NA RIMOKATOLIČKU I GRKOKATOLIČKU VJEROISPOVIJEST NA TERITORIJU ČAZMANSKOG ARHIĐAKONATA IZMEĐU 1941. I 1945.}

Poimenični popis osoba koje su zatražile prijelaz s pravoslavne na rimokatoličku vjeroispovijest sačuvan je na stranicama Urudžbenog zapisnika Nadbiskupskoga duhovnog stola u Zagrebu. Iz tih je popisa moguće rekonstruirati intenzitet konverzija u određenom razdoblju. Potrebno je naglasiti da su na popisu sve one osobe koje su zatražile prijelaz s pravoslavne na rimokatoličku vjeroispovijest, bez obzira na to jesu li te molbe poslije realizirale ili su zbog osnutka Hrvatske pravoslavne crkve ostale u svojoj vjeroispovijesti. ${ }^{6}$ Iz priloženoga tabličnog prikaza moguće je ustanoviti da je na

${ }^{6}$ Istraživanje vjerskih prijelaza iznimno je kompleksno zbog brojnih problema koji se pritom javljaju. Kao prvi i najveći problem valja istaknuti činjenicu da osobe koje su zatražile prijelaz na rimokatoličku, odnosno grkokatoličku vjeroispovijest nisu uvijek prešle na tu vjeroispovijest, već su odustajale od prijelaza, što nigdje nije bilo zabilježeno. Bilo je, dakako, i onih kojima prijelaz nije bio odobren, ali takvi su slučajevi uistinu bili rijetki. Kao drugi problem treba spomenuti da su kod masovnih vjerskih prijelaza ponekad ubilježeni i ljudi koji uopće nisu bili prisutni prilikom prekrštavanja, odnosno koji su se $\mathrm{u}$ tome trenutku nalazili ne samo izvan sela u nekom drugom dijelu NDH već i izvan $\mathrm{NDH}$ (najčešće u zarobljeništvu u Njemačkoj, pa i u Americi). Prilikom masovnih vjerskih prijelaza događalo se, iako ne osobito često, da su ubilježeni i ljudi koji su već preminuli. Popisi također nisu točni i zbog činjenice da su pojedinci bili ubilježeni više puta. Naime događalo se da su pojedinci podnosili molbu za vjerski prijelaz, a onda odgovor na tu molbu nije stigao dulje vrijeme, pa su župnici ponovno postavljali, pod drugim rednim brojem, pitanje Nadbiskupskome duhovnom stolu za iste pojedince ili obitelji. Zbog toga je moglo doći i do ponavljanja osoba u konačnom popisu podnositelja molbi za vjerski prijelaz. Valja spomenuti i činjenicu da su mnoga imena i prezimena možda zapisana pogrešno. Naime budući da je većina dokumenata pisana rukom, a pojedini župnici nisu imali posve čitljiv rukopis, moglo je lako doći do navođenja pojedinih pogrešnih imena i prezimena u popisu osoba koje su zatražile prijelaz. Spomenimo i činjenicu da kod pojedinih osoba u Urudžbenom zapisniku Nadbiskupskoga duhovnog stola nije stajalo s koje vjeroispovijesti na koju prelaze. Tako nije s potpunom sigurnošću moguće ustanoviti jesu li svi na popisu pravoslavne vjeroispovijesti, odnosno ne nalaze li se među popisanima i pojedini Zidovi, starokatolici, evangelici ili muslimani. Najčešće su pogreške toga tipa one gdje su u popis upisani starokatolici (koji se po svojim imenima i prezimenima ne razlikuju od pravoslavaca), odnosno Židovi (za koje je također ponekad teže ustanoviti da su židovske vjeroispovijesti). Još jedan problem koji se javlja jest činjenica da osobe koje su zatražile prijelaz nisu uvijek sve poimenično navedene. U popisima prijelaznika zapisan je eventualno samo kućedomaćin te napomena da prelazi na primjer šest članova obitelji (nije uvijek posve jasno prelazi li uz njega šest članova obitelji ili sveukupno šest članova obitelji). U pojedinim župama postoje podaci da prelazi 150 prijelaznika, da prelaze pojedina sela, da prelazi toliko i toliko obitelji i slično, ali nam nisu sačuvani popisi pri- 
području Moslavine najintenzivnije razdoblje podnošenja molbi za prijelaz s pravoslavne na rimokatoličku vjeroispovijest bilo u drugoj polovini 1941. (župe Križ, Kutina, Dapci, Čazma i Garešnica) i u prvoj polovini 1942. (Kaniška Iva, Tomašica, Štefanje, Hercegovac i Grubišno Polje) (tablica 1). Daleko najveći broj prijelaza obavljen je u župi Kaniška Iva, južno od Garešnice, gdje je praktično u godinu dana (1941./1942.) konvertiralo više 1400 osoba. Činjenica je da je većina tražitelja prijelaza od Nadbiskupskoga duhovnog stola dobila dozvolu, ali kao što smo rekli, ne možemo tvrditi da su svi koji su zatražili prijelaz i dobili dozvolu da prijeđu, zaista i konvertirali. Nešto veći broj podnesenih molbi za vjerski prijelaz zabilježen je u župama Grubišno Polje, Kutina i Tomašica. U pojedinim župama vidljivo je da su prešli tek pojedinci, odnosno ako je bilo malo pravoslavnih žitelja, da je prešla tek jedna ili dvije obitelji. Takvi su slučajevi u župama u Posavskim Bregima, Voloderu, Vrtlinskoj, Staroj Ploščici, Osekovu, Ludini, Ivanić-Gradu i Ladislavi. Uglavnom je riječ o župama gdje nikada nije bilo pravoslavnog stanovništva, odnosno koje su oduvijek bile vjerski gotovo monolitne. Ipak, broj od 3271 osobe koja je zatražila prijelaz s pravoslavne na rimokatoličku vjeroispovijest govori o masovnosti te pojave, posebno u župi Kaniškoj Ivi, čiji prijelaznici čine gotovo 50\% prijelaznika Čazmanskog arhiđakonata. Valja upozoriti i na prijelaznike, njih najmanje 751, s područja naselja Mikleuške nedaleko od Kutine koji nisu na poimeničnim popisima, nego je za njih

jelaznika. Kao kontrolni dokumenti služe nam dokumentacija koju su župnici slali Nadbiskupskome duhovnom stolu 1944. i dokumentacija Interdijecezalnoga vjerskog odjela iz koje je vidljivo koliko je bilo onih koji su uistinu prešli. Kod nekih župa ti se podaci savršeno slažu (pogrešno je navedena jedna ili dvije osobe), ali to je slučaj kod župa kod kojih je bio relativno mali broj prijelaza, dok se kod drugih brojevi razlikuju i po nekoliko tisuća. Obično su brojevi koje donose župnici veći od brojeva do kojih smo došli izradom poimeničnih popisa, što je logično, jer nisu svi zabilježeni zbog nedostatka dokumenata koji bi nam to omogućili. Ipak, postoje i iznimke gdje su brojevi župnika manji od brojeva do kojih smo došli izradom poimeničnih popisa. Ponekad su župnici u svojim sumarnim izvještajima donosili podatke o onim prijelaznicima koji su upisani u knjige prijelaza, ali ne i o onima koji su masovno prelazili, a koji nisu bili nigdje upisivani. Slična je situacija i na području župa koje su bile ustanovljene za prijelaznike, kao na primjer Mikleuška, gdje nemamo uopće, ili imamo samo neznatno malo osoba koje su poimenično popisane, ali znamo točni broj onih koji su prešli na rimokatoličku vjeroispovijest. Takvih je slučajeva bilo i kod prijelaza s pravoslavne na grkokatoličku vjeroispovijest u župama Moslavine. O broju prijelaznika na tim teritorijima saznajemo jedino iz iskaza križevačkog vladike Janka Šimraka organima Odjeljenja za zaštitu naroda (OZN-a) nakon Drugoga svjetskog rata, koji spominje da su čitave parohije prelazile na grkokatolički obred, ali da osobe nigdje nisu bile upisivane, pa nam ovdje čak nisu poznati ni točni brojevi prijelaznika. Iz svih ovih metodoloških problema koji su nastajali prilikom izrade popisa jasno je s koliko se opreza treba koristiti brojevima navedenima u ovom radu i koliko su relativni rezultati do kojih se došlo istraživanjem toga materijala. Prava je šteta što nam nisu sačuvane knjige prijelaza koje bi nam dale nedvosmislenu informaciju o tome tko je prešao na rimokatoličku, odnosno grkokatoličku vjeroispovijest na području čitave Zagrebačke nadbiskupije. 
bila osnovana posebna župa (NAZ, NDS, 222-IVO-1942). U ostalim župama nije bilo masovnijih vjerskih prijelaza.

Valja također upozoriti i na veća neslaganja broja prijavljenih za prijelaz s pravoslavne na rimokatoličku vjeru prema Urudžbenom zapisniku Nadbiskupskoga duhovnog stola s brojem onih koji su prešli na rimokatoličku vjeroispovijest a koje donose pojedini župnici u kumulativnom izvještaju Nadbiskupskome duhovnom stolu iz 1944., dakle na samom kraju rata (tablica 2). Tako je broj od šest prijelaznika na području župe Hercegovca, koju 1944. donosi hercegovački župnik, u neskladu sa 121 podnesenom molbom za prijelaz, koliko je zabilježeno u dokumentima Nadbiskupskoga duhovnog stola. U neskladu je i broj od 42 prijelaznika na području župe Ivanske sa 151 molbom za prijelaz zabilježenom u dokumentima Nadbiskupskoga duhovnog stola, kao i broj od svega 27 prijelaza na području župe Tomašice sa zabilježenih 209 prijava za prijelaz. Evidentno je da je na području župa u Tomašici i Ivanskoj, pa i u Hercegovcu, bilo mnogo onih koji su podnijeli molbe za prijelaz, ali su ih u travnju 1942. zbog osnutka Hrvatske pravoslavne crkve povukli, odnosno pitanje vjerskog prijelaza zanemarili. Dakle moguće je da su pravoslavni vjernici smatrali da formiranjem Hrvatske pravoslavne crkve nema više smisla prelaziti na rimokatoličku vjeroispovijest, kada je Hrvatska pravoslavna crkva bila priznata od vlasti NDH. Većina se drugih brojeva više-manje podudara (Čazma, Dapci, Križ, Ludina i Posavski Bregi). Za ostale župe, nažalost, ne posjedujemo nikakve podatke župnika iz 1944. iz kojih bismo mogli očitati broj vjerskih prijelaza. Za pojedine župe, poput garešničke, posjedujemo podatke o broju prijelaznika od travnja 1941. do veljače 1942., ali ti se rezultati ne poklapaju s našim rezultatima koji su dobiveni izradom poimeničnog popisa. Tako je garešnički župnik izvijestio Nadbiskupski duhovni stol da je u tome razdoblju na rimokatoličku vjeroispovijest prešlo 75 pravoslavnih, 1 starokatolik i 14 Židova, a prema poimeničnom popisu onih koji su zatražili prijelaz s pravoslavne na rimokatoličku vjeroispovijest 1941. i 1942. bilo ih je 137 (NAZ, NDS,150-IVO-1942). ${ }^{7}$

Dodatni su nam izvor podaci Hrvatskoga državnog arhiva, fonda Odjela bogoštovlja Ministarstva pravosuđa i bogoštovlja NDH te fonda Vjerskog odsjeka Državnog ravnateljstva za ponovu. Tako se prema dokumentima iz Vjerskog odsjeka Državnog ravnateljstva za ponovu na području kotara Čazme do sredine prosinca 1941. za prekrštavanje prijavilo dvanaest pravoslavaca, dok ih je 43 već prekršteno na rimokatoličku vjeroispovijest (HDA,

Razliku u broju vjerskih prijelaza možemo objasniti činjenicom da je ostatak od 62 pravoslavca prešao na rimokatoličku vjeroispovijest između veljače i prosinca 1942. 
DRP-VO, kutija 584, 642/1941), a tijekom prosinca 22 osobe (zatražilo prekrštavanje četrnaest osoba, a za prekrštavanje se nisu najavile 392 osobe) (HDA, DRP-VO, kutija 584, 773/1941). Iz statističkih podataka o broju prekrštenih na garešničkom području vidljivo je da je od ukupno 6136 pravoslavnih žitelja na području kotara Garešnice, njih 3823 zatražilo potvrdu o čestitosti »u svrhu prijelaza na rimokatoličku vjeroispovijest «, dok ih 2313 nije zatražilo »prijelaz« (HDA, MPB NDH, OB, kutija 46, 7060 - B - 1942). Na području čitave kotarske oblasti Kutine do početka prosinca 1941. prekrštena su 1073 pravoslavca, najavila prekrštavanje 292 pravoslavca, a nisu najavila prekrštavanje 222 (HDA, DRP-VO, kutija 584, 551/1941). Na području općine Grubišnog Polja, od 3321 pravoslavca koliko ih je »najavilo je prijelaz « na rimokatoličku vjeroispovijest svega je njih 67 prekršteno, na području Ivanova Sela od 1844 pravoslavaca prekršteno je svega 68, a na području Velikoga Grđevca od 3040 svega je njih 68 prekršteno do sredine studenoga 1941. (HDA, DRP-VO, kutija 584, 277/1941).

Tablica 1. Broj prijelaznika po godinama za pojedine župe $\mathrm{u}$ Čazmanskom arhiđakonatu

Table 1. Number of religious conversions by years and selected parishes of archdeaconry of Čazma

\begin{tabular}{lrrrrrr}
\hline Župa & $\mathbf{1 9 4 1 .}$ & $\mathbf{1 9 4 2 .}$ & $\mathbf{1 9 4 3 .}$ & $\mathbf{1 9 4 4 .}$ & $\mathbf{1 9 4 5 .}$ & Ukupno \\
\hline Čazma & 106 & 20 & 1 & 0 & 0 & 127 \\
\hline Dapci & 40 & 0 & 0 & 0 & 0 & 40 \\
\hline Dubrovčak & 0 & 1 & 0 & 0 & 0 & 1 \\
\hline Garešnica & 97 & 39 & 0 & 1 & 0 & 137 \\
\hline Gornja Jelenska & 0 & 1 & 0 & 0 & 0 & 1 \\
\hline Grubišno Polje & 109 & 262 & 12 & 0 & 0 & 383 \\
\hline Hercegovac & 1 & 120 & 0 & 0 & 0 & 121 \\
\hline Ivanić-Grad & 7 & 10 & 2 & 0 & 0 & 19 \\
\hline Ivanska & 0 & 151 & 0 & 0 & 0 & 151 \\
\hline Kaniška Iva & 83 & 1381 & 0 & 1 & 0 & 1465 \\
\hline Kloštar Ivanić & 34 & 20 & 0 & 0 & 0 & 54 \\
\hline Križ & 135 & 19 & 0 & 0 & 0 & 154 \\
\hline Kutina & 184 & 10 & 5 & 0 & 2 & 201 \\
\hline Ladislav & 1 & 0 & 0 & 0 & 0 & 1 \\
\hline Ludina & 22 & 0 & 0 & 0 & 0 & 22 \\
\hline Osekovo & 8 & 0 & 0 & 0 & 0 & 8 \\
\hline Posavski Bregi & 2 & 1 & 0 & 0 & 0 & 3 \\
\hline Samarica & 23 & 13 & 16 & 0 & 0 & 52 \\
\hline & & & & & &
\end{tabular}




\begin{tabular}{lrrrrrr}
\hline Župa & $\mathbf{1 9 4 1 .}$ & $\mathbf{1 9 4 2 .}$ & $\mathbf{1 9 4 3 .}$ & $\mathbf{1 9 4 4 .}$ & $\mathbf{1 9 4 5 .}$ & Ukupno \\
\hline Stara Ploščica & 4 & 0 & 0 & 0 & 0 & 4 \\
\hline Štefanje & 11 & 92 & 0 & 0 & 0 & 103 \\
\hline Tomašica & 10 & 199 & 0 & 0 & 0 & 209 \\
\hline Voloder & 6 & 5 & 0 & 0 & 0 & 11 \\
\hline Vrtlinska & 0 & 4 & 0 & 0 & 0 & 4 \\
\hline Ukupno & $\mathbf{8 8 3}$ & $\mathbf{2 3 4 8}$ & $\mathbf{3 6}$ & $\mathbf{2}$ & $\mathbf{2}$ & $\mathbf{3 2 7 1}$ \\
\hline
\end{tabular}

Izvor: NAZ, Urudžbeni zapisnik Nadbiskupskog duhovnog stola za godine 1941. - 1945.

Tablica 2. Broj prijelaza prema izvještaju pojedinih župnika Nadbiskupskome duhovnom stolu 1944.

Table 2. Number of religious conversions according to the reports of selected pastors submitted to the Archiepiscopal Curia in 1944

\begin{tabular}{lc}
\hline Župa & $\begin{array}{c}\text { Broj prijelaznika s pravoslavne } \\
\text { na rimokatoličku vjeroispovijest } \\
\text { do 1944. }\end{array}$ \\
\hline Čazma & 126 \\
\hline Dapci & 38 \\
\hline Hercegovac & 6 \\
\hline Ivanić-Grad & 39 \\
\hline Ivanska & 42 \\
\hline Križ & 141 \\
\hline Ludina & 25 \\
\hline Posavski Bregi & 2 \\
\hline Tomašica & 27 \\
\hline
\end{tabular}

Izvor: NAZ, Nadbiskupski duhovni stol, 2658/1944.

\section{POJEDINAČNI VJERSKI PRIJELAZI NA PODRUČJU ČAZMANSKOG ARHIĐAKONATA}

Na području Čazmanskog arhiđakonata bilo je mnogo pojedinačnih vjerskih prijelaza. Najčešći oblik vjerskih prijelaza s pravoslavne na rimokatoličku vjeroispovijest u Moslavini bili su prijelazi pojedinaca, odnosno pojedinih obitelji. Zabilježena su tek dva masovna vjerska prijelaza, u Kaniškoj Ivi i u Mikleuškoj. Kronološki, prva najava vjerskog prijelaza s pravoslavne na rimokatoličku vjeroispovijest bila je 28. travnja 1941. u Kloštar Ivaniću, kad je Milan Magdić podnio molbu za vjerski prijelaz (NAZ, NDS, 
4039/1941). Na području Kloštar Ivanića živio je mali broj Srba, koji su vrlo brzo nakon uspostave NDH podnijeli molbe za vjerski prijelaz. Nakon tih molbi slijedile su, početkom svibnja 1941., tri molbe na području župe Garešnice, koje su podnijeli Petar Petrov (NAZ, NDS, 4131/1941), Milan Milek (NAZ, NDS, 4191/1941) i Božidarka Mihaljić (NAZ, NDS, 4401/1941). Tek ova posljednja molba podnesena je nakon Zakonske odredbe o prijelazu s jedne vjere na drugu, koja je donesena 3. svibnja 1941. Prva obiteljska molba podnesena je 13. svibnja 1941. u Garešnici, kada je supruga Nikole Kajgane, Olga Kajgana, zatražila od župnika u Garešnici da se njoj, koja je prije bila katolkinja, njezinoj djeci i njezinu suprugu omogući prijelaz na rimokatoličku vjeroispovijest. Župnik ističe da je Olga »uvijek odlazila na bogoslužje u rimokatoličku crkvu u Garešnici i da je svoju djecu odgajala u katoličkom duhu, pa se može vjerovati u iskrenost ove molbe«. Župniku je Nadbiskupski duhovni stol odgovorio da su potrebne potvrde od kotarskih vlasti o čestitosti članova obitelji i da je potrebno da članovi obitelji prođu poduku (NAZ, NDS, 4675/1941).

Uobičajena procedura za vjerski prijelaz bila je da se od kotarskih vlasti zatraži potvrda o čestitosti. Tu potvrdu mogao je izdati i ustaški tabor ili općinske vlasti, a tek nakon poduke o rimokatoličkoj vjeroispovijesti koju bi molitelji prošli župnik je podnosio molbu Nadbiskupskome duhovnom stolu. Stol bi na kraju odobrio ili ne bi odobrio prijelaz. U kasnijem razdoblju, a posebno prilikom masovnih prijelaza, kotarske ili općinske vlasti mnogo su rjeđe izdavale potvrde o čestitosti, već bi župnik samo zatražio odobrenje za prijelaz od Nadbiskupskoga duhovnog stola. Dakako, za sve potvrde i molbe plaćalo se biljege. Ponekad su uz molbe pojedinih župnika sačuvane i potvrde o čestitosti. Općinsko poglavarstvo trgovišta u Čazmi izdalo je Vladimiru Stamboliji iz Čazme »svjedočbu čestitosti«. U njoj je stajalo da je Stambolija »čestita osoba dobrog ponašanja te da sudski a niti politički do sada nije kažnjen « (NAZ, NDS, 12409/1941).

U Križu su Židovi i Srbi zajedno tražili prijelaz. Tako su Korač Nikola, Korač Stjepan i Kosić Darinka tražili da prijeđu na rimokatoličku vjeroispovijest, a Dragutin Reisner, Židov iz Novoselca, tražio je da se pokrsti. Župnik iz Križa sve je molbe preporučio, a istaknuo je kako se »posebna pažnja poklanja poučavanju u vjeri« i kako se oko toga posebno trudi spomenuti Židov Reisner (NAZ, NDS, 6173/1941). Upravo je molba Franciske Radanović specifična. Naime Francisku je ostavio njezin suprug pravoslavne vjeroispovijesti, pa je već 1939. željela svoja dva sina Vukašina i Veljka prevesti na rimokatoličku vjeroispovijest, kojoj je i sama pripadala. Tada ju je župnik u Garešnici uputio na sud, da putem suda prevede svoju djecu 
na rimokatoličku vjeroispovijest. Ona je s tim otezala i tako dočekala 1941. godinu, kad joj garešnički župnik, na temelju dozvole Nadbiskupskoga duhovnog stola, omogućuje da prevede djecu na rimokatoličku vjeroispovijest. Nakon toga Franciska je tražila da se djeci promijene imena Vukašin i Veljko u neka »manje srpska imena«. Nadbiskupski duhovni stol uputio je Francisku da se za promjenu imena obrati državnim, kotarskim vlastima (NAZ, NDS, 6828/1941).

Na području Garešnice uslijedile su u srpnju 1941. učestalije molbe za primanje u rimokatoličku vjeroispovijest zbog pojave organiziranoga prisilnog iseljavanja Srba u logor Bjelovar i Požegu, odakle su zatočenici trebali biti prisilno iseljeni u Srbiju. Među podnositeljima molbi bilo je različitih slučajeva. Tako je Marko Jovanović, »ciganin, koji živi u konkubinatu sa cigankom i ima dvoje nezakonite djece krštene u rkt. Crkvi«, tražio da prijeđe s pravoslavne na rimokatoličku vjeroispovijest. Danica Marević, neudata služavka, ima zaručnika rimokatolika, pa i ona želi prijeći na rimokatoličku vjeroispovijest. Milka Šmit vjenčana je u pravoslavnoj crkvi s evangelikom Konradom Šmitom, ali se od njega rastala nakon šest mjeseci i sad služi u Velikom Grđevcu, također moli prijelaz. Garešnički župnik traži za ukupno sedamnaest osoba da ih se 15. srpnja 1941. primi u Rimokatoličku crkvu. Ipak, svjestan je činjenice da dio tih osoba živi u konkubinatu i da su, usprkos tome što sada obećavaju da će prestati živjeti izvan braka, izgledi za to vrlo mali. Župnik smatra da je »bolje da se takve osobe ipak prime, jer će inače prijeći na islam ili na evangeličku vjeroispovijest i tako ćemo imati ovdje usred hrvatskog naroda opet razdor« (NAZ, NDS, 10333/1941). Sličan je "problem « imao i župnik iz Kloštar Ivanića koji je želio prevesti na rimokatoličku vjeroispovijest Dušana Kokotovića, podvornika u tamošnjoj Pučkoj školi. »Potpisani njegovu molbu Preč. Naslovu preporučuje iz razloga, da isti u ovom pritisku, koji se na grkoistočne sada čini, ne predje možda na protestantizam, što bi bilo vrlo nezgodno« (NAZ, NDS, 2620/1942). Antonije Brkić, privatni namještenik u Grubišnom Polju, rođen 1903. u Kukunjevcu, već je 4. lipnja 1941. preko svoje supruge Margite, koja je po rođenju bila rimokatolkinja, tražio prijelaz za sebe, za svoje dvoje djece i, dakako, za suprugu, koja je »otpala od rimokatoličke vjere«. Brkić je, kako se čini, bio zaposlen u nekom poduzeću gdje mu je prijetio otkaz zbog toga što je bio Srbin. Prijelaz mu je odobren tek nakon molbe koju je grubišnopoljski kapelan 24. kolovoza 1941. podnio Nadbiskupskome duhovnom stolu (NAZ, NDS, 11741/1941).

$\mathrm{Na}$ rimokatoličku vjeroispovijest prešao je, zajedno sa suprugom Milicom i kćeri Bogdankom, i veterinar Bogdan Rašeta rođen 1904. u Plaškom. 
On je u svojoj molbi napisao da želi prijeći na rimokatoličku vjeru »jer sam uvjeren u njezino Božansko porijeklo i znam, da se ljudi samo u njoj mogu spasiti« (NAZ, NDS, 8956/1941). Bila je to jedna od formulacija kojom su se objašnjavali razlozi vjerskog prijelaza, a podnositeljima molbi bila je nada u trenutačni spas. Molbu je, po ovlaštenju župnika, 12. srpnja 1941. preporučio grubišnopoljski kapelan, a već je 18. srpnja 1941. Nadbiskupski duhovni stol potvrdio prijelaz. Tako rani prijelaz, u prvoj polovini srpnja 1941., kad s područja kotara Grubišnog Polja još nisu poduzeta organizirana masovna prisilna iseljavanja Srba u Srbiju, trebao je značiti sigurnost za Rašetu, odnosno osigurati mu daljnji rad kao kotarskog veterinara u Grubišnom Polju.

Branko Pokrajac sa suprugom Marijom i sinom Dragojem iz Malih Zdenaca donio je grubišnopoljskom župniku potvrdu civilnih vlasti, u ovom slučaju kotarskog nadstojnika iz Grubišnog Polja, da je »s obzirom na svoju dosadašnju čestitost, vrijedan da bude primljen u rimokatoličku crkvu«. Za tu potvrdu Branko i njegova obitelj platili su dvadeset kuna biljega. Takve su potvrde morali priložiti svi koji su željeli prijeći na rimokatoličku vjeroispovijest (NAZ, NDS, 12779/1941). Sličnu potvrdu izdao je općinski načelnik iz Grubišnog Polja Ljubici, Jovanki i Ranki Petrović. U potvrdi je stajalo da su moliteljice »dobrog moralnog ponašanja« i da potvrda može poslužiti kao "prilog k molbi za prijelaz iz grčko istočne vjere na rimokatoličku vjeru« (NAZ, NDS, 12780/1941). Kao i kod ostalih, na poleđini molbe stajalo je aff., što je značilo da su primljene u rimokatoličku vjeroispovijest.

Na području kotara Čazme, gdje se očito već prije organiziranoga prisilnog iseljavanja Srba s područja NDH o tome govorilo, Luka Puhača i Marica Puhača iz Marinkovca 15. srpnja 1941. traže da im se izda potvrda da su u kotarskoj oblasti u Čazmi izjavili da svojom voljom prelaze s pravoslavne na rimokatoličku vjeroispovijest. Župnik u Čazmi naplatio je bračnom paru Puhača 150 dinara biljega za prijelaz na rimokatoličku vjeroispovijest 18. srpnja 1941. (NAZ, NDS, 10845/1941). Interesantna je činjenica da župnik u Garešnici piše Nadbiskupskome duhovnom stolu da pojedini pravoslavci iz župe Samarice dolaze u župu Garešnicu zbog visokih taksa koje ubire župnik u Samarici. »Isti su se grčkoistočnjaci potužili na rkt. župnika u Samarici da bezobzirno traži i ubire taksu od 200 kuna po duši za prijelaz. Bogatiji da i to plaćaju, a siromašniji ne znaju, šta bi. Budući da takav postupak vrlo ružno svijetlo baca na našu vjeru baš sada, kada se radi o tome, da ovi prelaznici upoznaju u našoj Crkvi ljepotu i savršenost prave Kristove Crkve, to molim preč. Naslov, da takvom postupku energično učini kraj. Možda je i taj postupak jedan od razloga, da bježe ovamo i traže ovdje utočište « (NAZ, NDS, 17470/1941). Iz dopisa je vidljivo i to da je župnik u Garešnici 
primao pravoslavne obitelji iz Velikog Prokopa, koji je potpadao pod župu u Samarici (NAZ, NDS, 17470/1941).

Pojedini su roditelji u strahu za svoju djecu tražili dozvolu za vjerski prijelaz djece koja su bila pravoslavne vjeroispovijesti. Tako je Vika Gajdašević najavila prijelaz na rimokatoličku vjeroispovijest za svoju kćer Đurđicu, rođenu 1930. u Križu. Dijete je bilo pravoslavne vjeroispovijesti jer je Vikin pokojni suprug bio pravoslavac. Đurđica je, kako piše župnik iz Križa, »dobro poučena u vjeri, jer je ostajala uvijek pod satom vjeronauka, svake nedjelje je dolazila u našu crkvu te ima veliku želju da bude rimokatolkinja« (NAZ, NDS, 10923/1941). Osobito mnogo slučajeva vjerskih prijelaza bilo je kod osoba koje su bile u vjerski i nacionalno mješovitim brakovima. Tako je Ive Juretić, koji je prije vjenčanja prešao na pravoslavnu vjeroispovijest, tražio 21. srpnja 1941. od župnika Đurića u Kaniškoj Ivi da njega i njegovu obitelj prevede na rimokatoličku vjeroispovijest. Đurić je u molbi Nadbiskupskome duhovnom stolu istaknuo da je njegova izjava »ozbiljna i da potiče iz vjerskih razloga, pa da stoga umoljava prečasni naslov da njihov primitak u vjeru rimokatoličku dozvoli« (NAZ, NDS, 11412/1941). Kao najčešći razlog vjerskog prijelaza ističe se vjerska cjelovitost obitelji. Kad kutinski župnik moli za prijelaz Ljubomira Brankovića iz Kutine, ističe da je »svetkovao svoje i katoličke blagdane te nije nikada dirao u vjerske osjećaje svoje supruge. Kako želi da cijela obitelj bude katolička i da se utvrdi brak, to molim Prečasno isti, da izvoli molbu uvažiti« (NAZ, NDS, 11487/1941). Isti kutinski župnik moli i za Miloša Vujnovića. Prilikom molbe citira Miloševe riječi: »Medju katolicima sam, veli on, pa neću biti bijela vrana. Što vjeruju katolici vjerujem i ja, kako žive oni i ja ću, kako će biti njima i meni će tako biti« (NAZ, NDS, 11655/1941). Kutinski župnik i prilikom pisanja molbe za Milana Bižića i njegova sina Milana piše: »Značajno je kao i kod ostalih pravoslavaca, koji imadu žene katolkinje, da su štovali katoličku vjeru i svetkovali katoličke blagdane, pa da nisu došle sadanje prilike, tko zna ne bi li sami po sebi prešli na katolicizam« (NAZ, NDS, 11659/1941). Čazmanski gruntovničar Vladimir Stambolija svoju je odluku da želi, zajedno sa sinovima Slobodanom i Brankom, prijeći na rimokatoličku vjeroispovijest obrazložio riječima da mu je »majka katolkinja, a i žena mi je katolkinja, pa želim, da ja i moja djeca pređemo na vjeru moje majke i žene (odnosno bake i majke - djeca) « (NAZ, NDS, 12409/1941). Nikola Popović iz Novoselca kod Križa moli za prijelaz na rimokatoličku vjeroispovijest 20. kolovoza 1941. zbog ukidanja pravoslavne parohije i svećenika u Križu, a kriški župnik ističe da su to inače »marljivi, mirni i pošteni radnici« (NAZ, NDS, 12509/1941). I Bogdan Čujić, učitelj iz Mikleuške kod Kutine, 
želi prijeći na rimokatoličku vjeroispovijest. Kako piše kutinski župnik, on potiče iz obitelji koja se "priznavala Hrvatima, jer mu je djed sudjelovao s Kvaternikom u Rakovičkoj buni, s njime i ubijen i pokopan u Rakovici. Kao učitelj, kada je kapelan bio zapriječen doći u školu, obučavao je djecu u vjeronauku, te mu je život bio više katolički nego pravoslavni. Bio bi i prije prešao na rimokatoličku vjeru, ali to zbog obzira prema rodbini nije učinio« (NAZ, NDS, 16033/1941). Zanimljiv je slučaj Milana Dopudje iz Čazme koji traži od čazmanskog župnika da prijeđe na rimokatoličku vjeroispovijest. Ističe da je prije bio rimokatolik, ali je 1939. zbog namještenja prešao na pravoslavnu vjeroispovijest, pa se sada želi vratiti u rimokatoličku vjeroispovijest (NAZ, NDS, 15158/1941). I slučaj Jove Ranogajca i njegove supruge Marije je također zanimljiv. Naime Jovo je pri rođenju bio Ivan, ali se 1925. oženio u pravoslavnoj crkvi u Lipovčanima kod Čazme za Mariju Tatarin. Kod nje je služio kao sluga, a kada se želio oženiti, njezini su roditelji inzistirali da on prijeđe na pravoslavnu vjeroispovijest zato da na njega prenesu zemljište i dio kuće. U rujnu 1941. i Jovo i Marija žele prijeći zajedno sa svojim djetetom na rimokatoličku vjeroispovijest, a čazmanski župnik piše preporuku za taj prijelaz (NAZ, NDS, 15991/1941). Svi ti slučajevi pokazuju nam da su pojedinačne molbe za prijelaz najčešće podnosili upravo parovi iz nacionalno i vjerski mješovitih brakova. Župnik iz Samarice imao je poseban slučaj. On naime moli za djecu svoje sestrične: »Radu, Božu i Nevenku, stare 13, 8 i pet godina kojima je otac pravoslavne vjeroispovijesti, pa su i djeca pravoslavna. Sto puta se kajala [sestrična] što se udala za pravoslavnog, no ja [župnik] nijesam mogao spriječiti, jer sam bio još dijete« (NAZ, NDS, 15543/1941). Neki župnici, poput onoga u Štefanju, bili su iznimno jednostavni u svojim molbama. Štefanjski župnik nabrojio je one za koje je tražio primanje $u$ rimokatoličku vjeroispovijest, a potom je napisao da "gore navedeni dobro poučeni, prelaze s uvjerenjem i da su im brakovi valjani«. Posebno je naglasio da svi imaju dozvole civilnih vlasti za prijelaz (NAZ, NDS, 2558/1942).

Zanimljivi su nam i omanji grupni prijelazi, iz kojih je jasno vidljivo koliko je politička situacija utjecala na intenzitet vjerskih prijelaza, odnosno na odustajanje od vjerskog prijelaza unatoč dobivenim dozvolama od civilnih vlasti. Od 7. studenog 1941. potječe molba pravoslavnih žitelja naselja Malog Pašijana, iz kojeg je osamnaest obitelji podnijelo molbu kotarskom predstojniku u Garešnici za prijelaz na rimokatoličku vjeroispovijest. Kao razlog prelaska kod svake se obitelji navodi: »jer želi ostati u ovoj zemlji i biti jedno s hrvatskim narodom te da bude, prema njegovoj izjavi, članom one crkve koja je jedina spasavajuća«. Sačuvana je i odluka kotarske oblasti u Gareš- 
nici od 8. studenog 1941. za žitelje sela Zdenčaca nedaleko od Tomašice. I ondje su mještani tražili prijelaz (8. studenog 1941.) te je kotarska oblast za dvadeset obitelji izdala rješenje da im se može odobriti zatraženi prijelaz (NAZ, NDS, 3521/1942). No tri mjeseca poslije, u veljači 1942., župnik iz Tomašice traži prijelaz za svega pet obitelji iz Zdenčaca, što bi značilo ili da nisu sačuvani svi dokumenti ili da je dio podnositelja molbe za prijelaz iz studenog 1941. odustao od svojeg zahtjeva (NAZ, NDS, 3526/1942). Nešto poslije, od veljače 1942., privremeni upravitelj župe u Tomašici Miloš Kristović pita Nadbiskupski duhovni stol da li da primi dvadeset osoba pravoslavne vjeroispovijesti iz Zdenčaca i Pašijana koji su se za "prijelaz prijavili silom prilika - da ne idu u vojsku« (NAZ, NDS, 4320/1942). To ne znači da i ostali nisu podnijeli molbe preko župnika iz Tomašice. Budući da je kao razlog navedena želja za ostankom u Hrvatskoj, očito je da su Srbi Malog Pašijana smatrali da im prijeti deportacija u Srbiju. Naime baš 7. studenog 1941. dio njihovih sunarodnjaka iz kotara Garešnice vraćen je kućama iz iseljeničkog logora u Požegi, pa je lako moguće da su Srbi Malog Pašijana za svaki slučaj reagirali smatrajući da im je najsigurnije da prijeđu na rimokatoličku vjeroispovijest. ${ }^{8}$

O tome kakvo je nepovjerenje vladalo prema onima koji su konvertirali govori dopis župnika iz Ivanske. Kad ga je Nadbiskupski duhovni stol krajem 1942. upitao za čistu nakanu prijelaza jedne omanje skupine pravoslavaca iz njegove župe, odgovorio im je: »Odgovaram, da ja nipošto ne mogu reći da oni imadu čistu nakanu za prijelaz. Obratno sam uvjeren. Razlog mojoj molbi je bio, što su oni mene srdačno prevarili. Iz obližnje obćine Gudovac prije nekih dvadesetak dana - tako sam naknadno doznao - selili su iz obćine mnogo pravoslavaca, pa su se preplašili pravoslavci i ove obćine i brže došli moliti. Mislio sam da će i mnogi drugi doći, koji su već dobili dozvolu još prije uskrsa, ali naskoro su se uvjerili, da iz ove obćine nikoga ne sele, pa je sada krivo i onima, koji su molili, jer ih više nema k meni ni blizu. Moja župa broji neko 800 pravoslavaca, a prešlo ih je ni 40 osoba na rimokal. vjeru, ali ni njih nikada nema ni k meni ni u crkvi. Pustimo ih na miru, na taj način nema govora o uvjerenju« (NAZ, NDS, 11800/1942).

S druge strane, štefanjski župnik pokazuje povjerenje prema svojim prijelaznicima. U dopisu koji je uputio u ožujku 1942. Nadbiskupskome duhovnom stolu, a u kojem je nabrojio 29 obitelji, naglasio je da »imade na području župe još nekih koji se sklanjaju preći i koji svakojakim došaptavanjem teroriziraju sve prelaznike. To ne govorim iz političkih razloga već

O tome vidi više u Škiljan, 2015 c: 159-160. 
da pokažem da se može kod navedenih prelaznika pretpostaviti dovoljnu dispoziciju koju traži Crkva da kome da prijelaz« (NAZ, NDS, 4010/1942). Župnik iz Štefanja zbog većeg je broja pravoslavaca koji su se prijavili za vjerski prijelaz u njegovoj župi zatražio jednog misionara (NAZ, NDS, 61IVO-1942). No čini se da je dio onih koji su se prijavili odustao od prijelaza, jer je vidljivo da je bilo svega 103 prijelaza na području župe.

Mnogo je manje bilo slučajeva prijelaza s pravoslavne na rimokatoličku ili grkokatoličku vjeroispovijest nakon osnutka Hrvatske pravoslavne crkve sredinom 1942. U dopisu župnika iz Ivanske od 22. travnja 1942. vidi se sumnja $\mathrm{u}$ trajnost prijelaza na rimokatoličku vjeroispovijest pravoslavaca koji su prešli na području njegove župe. »Kako je u njihovom srcu, to samo Bog dragi znade. Što osjećaju u svom srcu, nakon vijesti od 3. travnja, o osnutku hrvatske pravoslavne crkve, to je meni potpuno sakriveno. Oni se boje preda mnom otkriti svoje misli. [...] Ako se stvari promijene, ja držim, da će oni nanovo u svoju vjeru prijeći, iako su oni pokazali izvana veliku sklonost za K.C.« (NAZ, NDS, 4570/1942). U jednom drugom dopisu piše: »Bili svi pravoslavci zašutjeli odkako je priznata hrvatska pravoslavna vjera, i dosta njih je dobilo već dozvolu za prijelaz od Duh. Stola, ali su odustali« (NAZ, NDS, 11800/1942). Vidljivo je da župnik Nikola Stankić iz Ivanske nije znao što da radi. Bilo mu je jasno da odluke kotarskih vlasti o odobrenju prijelaza dolaze $u$ pitanje nakon priznanja Hrvatske pravoslavne crkve kao službene crkve na području NDH. U dopisu je još dodao da mu je jedna pravoslavna vjernica došla i kazala da »do 1 . svibnja neće prelaziti, jer se čuje, da će ostati u svojoj vjeri« (NAZ, NDS, 4570/1942).

Pojedini su župnici one koji su željeli prijeći na rimokatoličku vjeroispovijest nakon osnutka Hrvatske pravoslavne crkve odgovarali od njihove nakane. Kutinski župnik krajem 1942. odgovara obitelj Adjić od vjerskog prijelaza. »Dugo sam odgadjao da zatražim njihov prijelaz i upozorio sam ih da imadu sada pravoslavnu crkvu, ali oni ostadoše kod svoje odluke« (NAZ, NDS, 443/1943).

Najviše je pojedinačnih molbi potjecalo iz nacionalno i vjerski mješovitih brakova. Dio molbi podnijele su udovice ili rastavljene žene koje su se željele vratiti na rimokatoličku vjeroispovijest, odnosno one čija su djeca krštena u Pravoslavnoj crkvi, pa su sad tražile da se djeca prime u Rimokatoličku crkvu. Dio pojedinačnih molbi podnesen je iz straha pojedinaca koji su obnašali neku funkciju, odnosno iz straha da ne bi izgubili zaposlenje. Posebnu skupinu predstavljaju oni koji su bili u strahu od progona, odnosno koji su smatrali da bi mogli biti prisilno iseljeni iz svojih kuća, pa su stoga prelazili na rimokatoličku vjeroispovijest. Ipak, taj je razlog ponajviše 
prevladavao kod masovnijih, kolektivnih prijelaza. Vidljivo je također da se broj pojedinačnih i grupnih prijelaza smanjio nakon travnja 1942., odnosno nakon osnutka Hrvatske pravoslavne crkve. Pravoslavni su vjernici nakon osnutka Hrvatske pravoslavne crkve kalkulirali s vjerskim prijelazima, odnosno vrlo često odustajali od njega smatrajući da je država legalizirala njihovu vjeroispovijest, odnosno Crkvu.

\section{KOLEKTIVNI VJERSKI PRIJELAZI S PRAVOSLAVNE NA RIMOKATOLIČKU I GRKOKATOLIČKU VJEROISPOVIJEST}

Na području Moslavine bilo je svega nekoliko kolektivnih masovnih vjerskih prijelaza s pravoslavne na rimokatoličku vjeroispovijest. Kolektivnost i masovnost vjerskih prijelaza bila je karakteristična za sredine $u$ kojima su Srbi činili većinsko stanovništvo, kao na primjer neke dijelove Banije, sjeverni Kordun te zapadnu i istočnu Slavoniju, gdje su na rimokatoličku vjeroispovijest prelazila čitava sela. Jedan od masovnih prijelaza u Moslavini obavljen je u Moslavačkom Selištu. Stanovnici Moslavačkog Selišta poslali su poglavniku Anti Paveliću dopis u kojem su napisali kako su njihovi »preci doselili prije više stotina godina iz Like. I mada smo vjere grčko-istočne kroz toliki niz desetljeća srasli smo se sa ovom našom hrvatskom grudom i izmiješali sa našom braćom Hrvatima, s kojima živimo u nepomućenom miru i slozi tako da izmedju nas ni po osjećajima, a niti po ljubavi spram zajedničke nam domovine Hrvatske nema nikakove razlike. Jedino što nas vjera dijeli, no za ljubav spram Hrvatske nam domovine i spram jednokrvne braće Hrvata s kojima osjećamo jedno, pripravni smo zamijeniti vjeru naših otaca sa vjerom braće Hrvata i prijeći u crkvu rimokatoličku i time izbrisati svaku razliku i pokazati da smo jedno s braćom Hrvatima." Evidentno je da su se mještani Moslavačkog Selišta tog 27. rujna 1941., kad su u logor u Caprag otpremljeni njihovi sumještani da bi bili iseljeni u Srbiju, uplašili. Istoga su dana predstavnici 51 obitelji iz Moslavačkog Selišta napisali taj dopis poglavniku ističući kako od njega očekuju »zaštitu kao punopravnih građana«. Kutinski župnik preporučio je da se tamošnji seljaci, kao i seljaci iz Mikleuške i Kutinice, prime u Katoličku crkvu sutradan, odnosno 28. rujna 1941. (NAZ, NDS, 16648/1941).

Na području novoosnovane župe u Mikleuškoj župnik Želimir Liko nastupio je 23. prosinca 1941. No ondje nije imao ničega, pa je od Nadbiskupskoga duhovnog stola zatražio matične knjige, parice, status animarum, poštansku knjigu, papir i stara crkvena odijela. Njegov je zaključak: »Nemam ništa« (NAZ, NDS, 35-IVO-1942). U alarmantnom dopisu od 12. 
siječnja vidljivo je da Liko oskudijeva čak i u hrani, jer ne prima plaću. Ipak, nadobudno piše kako mora preurediti crkvu te kako je narod odličan i puni crkvu. Prema izvještaju župnika Lika, na području Mikleuške prešla je 751 osoba, a 36 ih je krajem travnja 1942. bilo u postupku prijelaza na rimokatoličku vjeroispovijest. Za Kutinicu župnik Liko nije imao popis, a broj prijelaznika bio je i veći (NAZ, NDS, 222-IVO-1942).

Posebni je slučaj selo Veliki Zdenci, gdje je dio pravoslavaca prešao na grkokatoličku vjeroispovijest. Naime u selu Dišniku, koje se od 1842. nalazilo u kotaru Garešnici, postojala je grkokatolička župa. U okružnici koju je izdalo Ministarstvo pravosuđa i bogoštovlja, Ministarstvo unutarnjih poslova, Glavni ustaški stan i Državno ravnateljstvo za ponovu, od 30. srpnja 1941., vidljivo je da je »želja hrvatske vlade« bila da »grkoistočnjaci ne prelaze na grkokatolički obred osim u onim grkokatoličkim župama koje su već osnovane i u njima ima grkoistočnjaka« (HDA, MPB NDH, kutija 18, 5601 - B - 1941). Grkokatoličko svećenstvo smatralo je da zbog župe u Dišniku ima pravo prekrštavati sve pravoslavce na području kotara Garešnice. Grkokatolički župnik Aleksandar Vlasov iz Dišnika agitirao je da dio pravoslavaca prijeđe na grkokatoličku vjeroispovijest, ali rimokatolički župnici to nikako nisu željeli. Rimokatolička crkva pokušavala je ocrniti Grkokatoličku crkvu prikazujući ih kao unijate koji nisu Hrvati. ${ }^{9}$ Posebno se protiv grkokatolika bunio nadstojnik Vjerskog ureda Državnog ravnateljstva za ponovu Dionizije Juričev, koji je isticao da više od dvije trećine grkokatolika u NDH nisu Hrvati te da su svećenici uglavnom stranci. Isto je tako smatrao, ne temeljeći taj svoj zaključak ni na jednom primjeru, da će pravoslavci prvom prilikom koja im se pruži prijeći s grkokatoličke vjeroispovijesti natrag na pravoslavlje (HDA, DRP-VO, kutija 584, 282/1941). ${ }^{10}$

Problemi su nastali na terenu kad je 24. srpnja 1941. odobren prijelaz 57 pravoslavnih obitelji na grkokatoličku vjeroispovijest u Velikim Zdencima. ${ }^{11}$ Svega dva dana nakon toga žitelji Velikih Zdenaca traže zaštitu od poglavnika Ante Pavelića i primanje u Rimokatoličku ili Grkokatoličku crkvu, tj. Hrvatsku narodnu zaštitu (HDA, MPB NDH, OB, kutija 42, 5285 - B 1942). Pravoslavnim žiteljima koji su prešli na grkokatoličku vjeroispovijest krajem srpnja 1941. taj je prijelaz 29. rujna 1941. poništen. U obrazloženju koje u prosincu 1941. šalje Velika župa Bilogora vidljivo je da se djelokrug dišničke župe nikako ne može protezati i na Velike Zdence, odnosno na sva pravoslavna sela u kotaru Garešnici, već isključivo na naselja u kojima ne

Vidi o tome dokument: HDA, MPB NDH, OB, kutija 18, 5590 - B - 1941.

10 O tim odnosima u Moslavini vidi i u: Škiljan, 2014: 155-162.

11 O tome prekrštavanju vidi iskaze u: Đurić, 1991: 165-166. 
postoje rimokatoličke župe te da stoga prijelaz pravoslavaca na grkokatoličku vjeroispovijest na tome području nije valjan. Potom su pravoslavni žitelji Velikih Zdenaca u dva navrata podnosili nove molbe za prijelaz na rimokatoličku vjeroispovijest, jednom u siječnju, a drugi put u veljači 1942. Župnik hercegovačke župe, pod koju je potpadalo selo Veliki Zdenci, obavještava Nadbiskupski duhovni stol da su u siječnju tražili prijelaz na rimokatolicizam svi oni koji su prije tražili prijelaz na grkokatoličku vjeroispovijest, čak i oni koji su već i formalno prešli na grkokatolicizam. Nešto prije toga dopisa župniku je 15. siječnja 1942. pisao garešnički dekan: »Zdenčani su dobili crkvenu dozvolu od grkokatoličkog ordinarijata, ali od državne vlasti je prva dozvola za grkokatolicizam poništena, i izdana je druga dozvola za rimokatolicizam. Državna vlast ostaje kod svoje dozvole i ne dopušta primanje u grkokat. Stvar prelaza je zrela, treba sada dakle nešto učiniti! Ako naš ordinarij dade dozvolu, onda možete odmah lično otići isusovcima i zamoliti za bar jednog misionara. O. Pašiček veli, da bi on mogao ići već na 2. veljače u V. Zdence... Ako pak naš ordinarij ne da dozvole radi bojazni, da ne povrijedi grkokatolike, tada se mora čekati i dalje. Ali da se naš ordinarij sklone na našu stranu, bilo bi dobro i potrebno, da sami pravoslavci zdenački, koji su dobili državnu dozvolu za prijelaz na rkt. pošalju sada odmah molbu na samog nadbiskupa, da budu primljeni u rkt. [...] Pazite da ne biste što na svoju ruku u tom pogledu učinili, jer će inače odmah preuzv. g. Šimrak tražiti Vašu suspenziju! To je dosta opasna stvar!« (NAZ, NDS, 78IVO-1942). Hercegovački župnik 5. veljače 1942. navodi trinaest obitelji koje žele s pravoslavne prijeći na rimokatoličku vjeroispovijest te za neke od njih napominje da su prije prešli na grkokatolički obred. »Kako je međutim državna vlast poništila prelaze grčkoistočnjaka na grkokatoličku vjeru, ti se prelaznici nalaze u velikoj duševnoj borbi, pa mole prečasni Nadbiskupski duhovni stol da što prije izdade svoju odluku da znadu na čemu su. Da ne dođe kasnije do borbe između grkokatolika i rimokatolika glede crkve u Velikim Zdencima, neka prečasni Nadbiskupski Duhovni Stol riješi ovu stvar kako najbolje znade« (NAZ, NDS, 147-IVO-1942). Hercegovački župnik pita Nadbiskupski duhovni stol zašto već 23. veljače 1942. nije donio rješenje za tih dvadeset obitelji koje su molile prijelaz. Nadbiskupski duhovni stol odgovara 6. ožujka 1942. hercegovačkom župniku da su prijelazi na grkokatoličku vjeroispovijest crkveno valjani te da je prepušteno križevačkom vladiki Janku Šimraku da uredi daljnje stanje u vezi s tim prijelazima. »Za sve pak, koji žele prijeći na rkt. vjeru iz Velikih Zdenaca podnesite posebnu molbu, u kojoj poimenice navedite sve prelaznike...« (NAZ, NDS, 174-IVO1942). Vidljivo je da je Interdijecezalni vjerski odbor 12. ožujka 1942. poslao 
Janku Šimraku dopis u kojem stoji da su »siromašni ljudi [misleći na pravoslavne iz Velikih Zdenaca koji su prešli na grkokatoličku vjeroispovijest] u najvećoj neprilici. Prešli su u katol. Crkvu, a vlast im to ne priznaje, dapače ih se progoni« (NAZ, NDS, 174-IVO-1942). Negdje krajem ožujka 1942. dopis nadbiskupu Stepincu piše iz Velikih Zdenaca i Miško Račan, bivši narodni zastupnik iz redova Hrvatske seljačke stranke. U svom pismu on savjetuje da u Velikim Zdencima pravoslavci ne prelaze na grkokatoličku vjeroispovijest, nego na rimokatoličku, jer ondje ima više rimokatolika, pa ne bi bilo zgodno da u selu budu tri crkve. Štoviše, preporučuje da pravoslavci na Bilogori, gdje su sela jednonacionalna i vjerski čista, prelaze na grkokatolicizam. Zanimljivo je da Račan napada Šimraka te piše da Šimrak »lomi koplje za 70 obitelji bivših pravoslavaca koji su momentalnom zabludom bili najavili prijelaz na grkoistočnu [sic!], a kasnije na rimokatoličku vjeru što medju ovdje postojećim rimokatolicima nije zgodno o tom činiti pitanje« (NAZ, NDS, 197-IVO-1942). Krajem travnja 1942. pojedinci iz Velikih Zdenaca dolaze u općinu Velike Zdence i potpisuju, svaki kućedomaćin pojedinačno za sebe i svoju obitelj, molbu da prijeđu na rimokatoličku vjeroispovijest. Tako na primjer Nikola Dobrijević izjavljuje: »Ja sam vjere grko istočne i do danas nisam tražio prijelaz na nikoju drugu vjeru. Kako je po vlasti vjera grko istočna dokinuta, a hoću da pripadam ipak jednoj priznatoj vjeri, to sam se odlučio da predjem skupa sa mojom porodicom na rimokatoličku vjeru, pa to ovim putem i činim i molim da se moja molba uvaži.« Na kraju se, 19. svibnja 1942., za prijelaz odlučilo svega pet obitelji, a ostale su formalno prešle na grkokatoličku vjeroispovijest, kako izvješćuje župnik iz Hercegovca. No čini se da je na grkokatoličku vjeroispovijest prešao od svake obitelji po jedan član, a da su tek poslije prelazili i još neki drugi (NAZ, NDS, 6511/1942).

Najmasovnije prekrštavanje na području Moslavine dogodilo se u župi Kaniškoj Ivi. Kako je napisao tamošnji župnik Josip Đurić, Kotarska oblast u Garešnici odobrila je početkom studenog 1941. prijelaz oko 2000 pravoslavnih vjernika na rimokatoličku vjeroispovijest na području župe Kaniške Ive. On je zatražio od Nadbiskupskoga duhovnog stola misionare da mu pomognu oko poduke i prijelaza tamošnjih pravoslavnih vjernika. Zahtijevao je da se odredi više osoba, barem šest misionara, i to dvojica za sela Veliko Vukovje, Malo Vukovje, Gojilo i dio Rogože, dvojica za Stupovaču, Brinjane, Čaire i Kutinicu te dvojica za Veliku Bršljanicu, dio Rogože i Malu Bršljanicu, tražeći i da sve troškove misionara snosi Državno ravnateljstvo za ponovu. Župnikov plan bio je da svi pravoslavni vjernici budu primljeni odjednom, a ako tako ne bude, istaknuo je da su mu onda dovoljna svega 
dvojica misionara (NAZ, NDS, 14-IVO-1942). Đurić je 20. studenoga 1941. otišao do ordinarija, koji mu je obećao da će mu poslati misionare. No do 11. prosinca 1941. misionari nisu stigli, pa Đurić ponovno piše kako pravoslavni vjernici neće moći prijeći ako se ne pošalju misionari (NAZ, NDS, 14-IVO-1942). Na dužnost misionara u Velikom Vukovju stupio je 16. prosinca 1941. otac Šantić (NAZ, NDS, 25-IVO-1942), a u Stupovači 19. prosinca 1941. otac Drnić, konventualac franjevac (NAZ, NDS, 23-IVO-1942). Uz njih je radio i otac Matija Pašiček, isusovac. Pašiček je, prema izvještaju župnika Đurića, poučavao pravoslavne u Malom Vukovju između 27. prosinca 1941. i 5. siječnja 1942. te u Velikoj Bršljanici između 5. i 19. siječnja 1942. Misionar Pašiček primio je u tim selima u rimokatoličku vjeroispovijest sve one kod kojih nije bilo nikakvih zapreka da ih se primi (NAZ, NDS, 67-IVO-1942). Pašiček je obavijestio Nadbiskupski duhovni stol da je između 17. siječnja i 1. travnja 1942. poučavao na području Stupovače te da je crkva bila »dupkom puna «. Dosta vjernika koji su željeli prijeći dolazilo je i iz sela Brinjana, Čaira, Kutinice i Rogože, »no prešlo ih je malo radi uređenja Hrvatske pravoslavne crkve, što se saznalo među njima na sam Uskrs. Čekaju točnije naredbe o tom uređenju ali se boje da bi to mogla biti samo politika bez koristi za njih, pa jedan drugoga nagovaraju na prijelaz na Rimokatoličku crkvu«. Za Veliko Vukovje Pašiček piše da je prešlo cijelo selo, osim par obitelji. »Na njihovu molbu predao je misionar crkvu kat. bogoslužju na bijelu nedjelju « (NAZ, NDS, 211-IVO-1942). Prema izvještaju župnika u Kaniškoj Ivi, od ukupno 916 pravoslavnih u Velikom Vukovju na rimokatoličku vjeroispovijest prešlo ih je 626 (NAZ, NDS, 239-IVO-1942). Župnik Đurić 13. srpnja 1942. potvrđuje Pašičekovo pisanje i ističe da nijedan od prijelaznika u župi Kaniškoj Ivi nije prešao na grkokatoličku vjeroispovijest. Prema izvještaju kotarske oblasti u Garešnici, 278 osoba na području bivše parohije Veliko Vukovje (njih 246 u Velikom Vukovju, dvadeset u Gojilu i dvanaest u Malom Vukovju) do 30. lipnja 1942. nije prešlo na rimokatoličku vjeroispovijest, dok na grkokatoličku vjeroispovijest nije prešla nijedna osoba. Župnik Đurić čak je sastavio i popis prijelaznika, njih 1372 s područja nekadašnje parohije Veliko Vukovje (NAZ, NDS, 239-IVO-1942). Sasvim drugačiji podatak o vjerskim prijelazima dao je Janko Šimrak, križevački vladika: »Tu je tražio od mene 141 kućegospodar prijelaz. Za to su me molili posljednji put kada sam bio u Dišniku, ali do danas ipak ništa nije učinjeno.«Šimrak je imao i kandidata za župnika u Velikom Vukovju. Bio je to dr. Stjepan Sakač (NAZ, NDS, 239-IVO-1942). 
O prekrštavanju u Velikom Vukovju postoji i autentičan zapis u memoarima S. D.-a iz Velikog Vukovja, rođenog 1918. On tvrdi da se prekrštavanje obavljalo pod prisilom, i to pod prijetnjom likvidacije. Prema pisanju S. D.a, župnik iz Kaniške Ive tražio je od Srba koji su dolazili na prekrštavanje da se znaju prekrižiti po katolički, da znaju Očenaš, Zdravomariju, Deset zapovjedi Božjih i još neke rimokatoličke molitve. S. D. tvrdi da Đuriću nije uspijevalo naučiti Srbe sve te nabrojene stvari i da ih je onda prekrštavao masovno, uz nekoliko svjedoka u crkvi. Kao i uvijek, u selu se nakon prvih informacija o tome da će se Srbe prekrštavati s pravoslavne na rimokatoličku vjeroispovijest počelo mnogo govoriti. Neki su smatrali da će dio Srba otjerati u Srbiju, a da će oni drugi imati privilegiju ostati u svojim domovima i kao lojalni pravoslavci moći primiti rimokatoličku vjeroispovijest. S. D.-ov sumještanin Savo Dejanović prisjeća se da je Đurić najčešće imao dobar odnos samo prema djeci, kojima je dijelio svete sličice i molitvenike. Iz crkve u Velikom Vukovju, prema njegovim riječima, izbačene su ikone, a crkva je preuređena tako da se u njoj može služiti rimokatoličko bogoslužje. Jovanka i Aleksandra Zajelac dale su iskaz S. D.-u u kojem ističu da je njihova majka, koja je bila učiteljica, morala isprazniti učionicu da bi se u njoj odvilo prekrštavanje. »U učionici je pop Đurić napravio oltar te je u učionici držao tri nedjelje mise, a potom su se u knjigu prijelaza morali svi upisati.« Prema riječima Aleksandre i Jovanke Zajelac, većina ljudi nije to učinila. Milka Drobac iz Malog Vukovja također je dala iskaz S. D.-u. Tvrdila je da je Đurić pravoslavcima prijetio Jasenovcem ako se ne prekrste te da je prekrštavanje obavio u osnovnoj školi neki misionar, a ne sam svećenik Đurić. Prekrštavanja u Velikom Vukovju prisjeća se i S. D. jer je tome činu sam prisustvovao. Ono se obavilo u osnovnoj školi 13. siječnja 1942. Nakon što je Đurić započeo s propovijedi, S. D. je pobjegao iz škole. Drugo prekrštavanje bilo je 9. veljače 1942. Na njemu je, navodno, Đurić optužio S. D.-a da je pobjegao s posljednjeg prekrštavanja i da je u njega ušao Lucifer. S. D. nije bio ni na tom prekrštavanju, a nakon povratka s njega sestra i majka natjerale su ga da ode do Đurića i prekrsti se na rimokatoličku vjeroispovijest. Kada je S. D. došao, rimokatolički svećenik bio je grub prema njemu i rekao mu da on »nije došao da se prekrsti, već da prijeđe u svoju staru pradjedovsku vjeru « (Dnevnik S. D.). ${ }^{12}$

U okolici Čazme, zbog većeg broja prijelaza, bilo je planirano osnivanje nove rimokatoličke župe u Narti, pod koju su trebala potpasti još dva sela u kojima je bilo pravoslavaca, Kolarevo Selo i Paljevine (NAZ, NDS, 22-

12 Uvid u dnevnik i kopije dao S. D. autoru u Zagrebu u rujnu 2015. 
IVO-1942). Iako je vladika Janko Šimrak tražio crkvu u Narti za bogoslužje grkokatolika, ${ }^{13}$ Interdijecezalni vjerski odbor zaključio je da je većina pravoslavaca u okolnim selima prešla na rimokatoličku, a ne grkokatoličku vjeroispovijest, pa bi crkva trebala pripasti rimokatolicima. Osim toga ističu da u Narti kao kapelan služi slovenski svećenik »koji vrlo lijepo radi«, pa je to još jedan razloga zašto bi u Narti trebala biti osnovana rimokatolička župa. Zato je, da ne bi došlo do pogreške, Interdijecezalni vjerski odbor tražio podatke od župnog ureda u Štefanju o točnom broju onih koji su prešli na rimokatoličku, odnosno grkokatoličku vjeroispovijest, tj. onih koji su ostali $\mathrm{u}$ pravoslavnoj vjeroispovijesti. U dopisu stoji da su, navodno, neki pravoslavci iz Narte otišli u Križevce i ondje tražili prijelaz na grkokatoličku vjeroispovijest. Na taj je dopis općinsko poglavarstvo u Ivanskoj odgovorilo da nema podataka o tome koliko je pravoslavaca prešlo na rimokatoličku vjeroispovijest, kao ni je li itko od stanovnika općine Ivanske tražio prijelaz na grkokatoličku vjeroispovijest (NAZ, NDS, 239-IVO-1942). Šimrak u svom dopisu Stepincu ističe da je župnik iz Štefanja »izbacio ikonostas iz pravoslavne crkve u Narti i da je nasred crkve stavio na zgražanje svih vjernika nekakvi stol i klupe iz židovske sinagoge u Bjelovaru. Medjutim, svi vjernici iz Narte su prešli na grkokatoličku vjeroispovied, pa žele, da im otvorimo crkvu i služimo. «Šimrak se bojao da će svi oni prijeći, kao što postoji opasnost i u Lipovčanima, u Hrvatsku pravoslavnu crkvu, pa da će njegov misionarski rad propasti. Naglašava da je župnik u Prgomeljama, grkokatoličkoj župi kod Bjelovara, istaknuo da su pravoslavci iz okolice Narte obavljali vjerske prijelaze u Križevcima, »jer nisu smjeli dolaziti u Prgomelje, budući da su im to branile mjesne vlasti«. Prgomeljski grkokatolički župnik ističe da su svega četiri obitelji iz Narte i okolice prešle na rimokatoličku vjeroispovijest, a ostala 61 pravoslavna obitelj na grkokatolicizam. Šimrak je naglasio da mu je stalo isključivo do spasa duša i do toga da pravoslavci slučajno ne prihvate Hrvatsku pravoslavnu crkvu, što bi značilo da je misija grkokatolika i rimokatolika na tome području propala (NAZ, NDS, 239-IVO-1942).

I na području Donjih Lipovčana trebala je pravoslavna crkva biti pretvorena u rimokatoličku bogomolju. To su tražili stanovnici toga naselja 30. travnja 1942. (NAZ, NDS, 192-IVO-1942). Prema odredbi Svete Stolice, ako je u Donjim Lipovčanima najveći broj stanovnika ostao pravoslavne

13 Prema svjedočenju Janka Šimraka organima OZN-e na području Bjelovara, Narte, Sredica, Gudovca, Prgomelja, Klokočevca, Starih i Novih Pavljana prešlo je oko 2000 vjernika. Formalni prijelaz učinili su samo činovnici i dobili su o tom svjedodžbu, dok ostali nisu prešli formalno (Bunjevac, 2005). 
vjeroispovijesti, onda se ta pravoslavna crkva nije mogla predati bilo kojoj drugoj crkvi. Prema izvještaju Interdijecezalnoga vjerskog odbora, u Donjim Lipovčanima je od 37 pravoslavnih obitelji devet prešlo na rimokatolički, a pet na grkokatolički obred te je Interdijecezalni vjerski odbor bio pripravan predati crkvu grkokatolicima »ako je većina grkoistočnjaka prešla na grkokatolički obred, što evidentno nije bio slučaj« (NAZ, NDS, 239-IVO-1942). Kotarska oblast u Čazmi dodijelila je 2. lipnja 1942. crkvu u Donjim Lipovčanima rimokatolicima (NAZ, NDS, 239-IVO-1942). ${ }^{14} \mathrm{Cr}$ kvu u Donjim Lipovčanima preuzeli su rimokatolici 14. lipnja 1942., o čemu postoji i zapisnik (NAZ, NDS, 239-IVO-1942). Zanimljivo je da je svega 3 dana prije, 11. lipnja 1942., Ministarstvo pravosuđa i bogoštovlja, Odjel za bogoštovlje, službeno naredilo Kotarskoj oblasti Čazma da preda crkvu u Donjim Lipovčanima grkokatolicima. No već sutradan Ministarstvo pravosuđa i bogoštovlja, Odjel bogoštovlja, stavlja izvan snage tu odredbu jer je crkva dodijeljena rimokatolicima (NAZ, NDS, 239-IVO-1942). Vladika Šimrak želio je 20. lipnja 1942. preuzeti crkve u Narti, Velikom Vukovju i Donjim Lipovčanima. No prije nego što je pošao na put, dobio je informaciju da je crkva u Donjim Lipovčanima predana rimokatolicima. Ipak, krenuo je preuzeti kapelicu u Marči. Kad je došao u Marču, dočekala ga je otvorena, poluopljačkana građevina, a od kotarske oblasti u Čazmi jedva je dobio ključeve kapelice (NAZ, NDS, 239-IVO-1942). Priča o Donjim Lipovčanima ima i svoju »prapovijest«. Prema pisanju vladike Šimraka, »svi kućegospodari iz sela Lipovčani poslali su mi ponovno dne 29. V. 1942. molbu da dodjem otvoriti tamošnju parohijalnu crkvu, jer su svi prešli na grkokat. vjeroispovijest. Medjutim došao je i tu kotarski predstojnik, koji je svakoga grkokatolika globio sa tri tisuće kuna i sa mjesec dana zatvora, koji sa grkokat. vjeroispovijesti nije htio prijeći na rimokatoličku. Medjutim i poslije tih drakonskih mjera nalazi se kod mene molba ljudi iz Lipovčana sa 47 podpisa kućegospodara, koji se izjavljuju grkokatolicima i koji žele, da im otvorim crkvu. Dakako da je razumljivo da se tamošnji ljudi nalaze u velikom strahu, jer su jedni protjerani, a drugima su zapalili stanje. Tako sam i u samoj Marči molio jednoga našega vjernika, da čuva ključe te kapele, ali

14 Već je kotarska vlast u Čazmi strogo 19. veljače 1942. zabranila pravoslavcima da prijeđu na grkokatoličku vjeroispovijest. »Povodom pokreta grkoistočnjaka da priedju na grkokatoličku vjeru, što je za ovo područje najstrože zabranjeno, izdan je nalog svim obćinama da obavieste sve grkoistočnjake, da pod prietnjom najstrožih zakonskih posljedica u roku od mjesec dana zatraže prijelaz na rimokatoličku vjeru, a u daljnjem roku od mjesec dana izvrše prijelaz na rkt. vjeru. « Iz toga je dopisa kotarske oblasti u Čazmi vrlo jasno da ustaške vlasti nikako nisu željele da pravoslavni Srbi prelaze na grkokatoličku vjeroispovijest (NAZ, NDS, 174-IVO-1942). 
je on to odbio s primjedbom, da se boji. Samo je sobom razumljivo, da su ti ljudi vrlo ozlojađeni i da jedva čekaju zgodnu priliku, da priedju na Hrvatsku pravoslavnu crkvu, kad im se krati prijelaz u grkokat. vjeroispovied.« Šimrak je usto molio Stepinca da mu omogući da u Donjim Lipovčanima Stanko Aljančić, franjevac koji je prešao na grkokatolički obred, drži službu nedjeljom i praznicima (NAZ, NDS, 239-IVO-1942).

\section{ZAKLJUČAK}

Iz ovih primjera masovnih prekrštavanja vidljivo je da je na svega nekoliko mjesta u Moslavini, na području Čazmanskog arhiđakonata, bilo masovnih prijelaza Srba s pravoslavne na rimokatoličku vjeroispovijest. Srbi su u selima oko Kaniške Ive u garešničkom kotaru i Mikleuške u kotaru Kutini masovno prelazili na rimokatoličku vjeroispovijest iz straha da ne budu iseljeni kao dio njihovih susjeda, a u Velikim Zdencima prešli su tijekom srpnja 1941. formalno na grkokatoličku vjeroispovijest. U pojedinim naseljima u kotaru Čazmi (Donji Lipovčani i Narta) Srbi su očito u manjem broju, pojedinačno, prelazili na grkokatolicizam, pa je dolazilo do sukoba oko nadležnosti nad pojedinim crkvenim objektima i parohijama između Rimokatoličke i Grkokatoličke crkve. Također treba primijetiti i da formalnih prijelaza na grkokatolicizam, osim pojedinih činovnika, u tim mjestima nije bilo. Vrlo je vjerojatno da su pojedini Srbi odlazili iz Velikih Zdenaca, Donjih Lipovčana i Narte, pa i drugih naselja u Moslavini, u Križevce da bi zatražili da neka sela prijeđu na grkokatoličku vjeroispovijest, ali je očito da usprkos dobroj volji Grkokatoličke crkve takvih masovnih prijelaza, barem $\mathrm{u}$ formalnom obliku, na tom području nije bilo. Uostalom, to su, kao što je vidljivo iz već napisanoga, sprečavale državne civilne vlasti, koje su se trudile, posebno na području Čazme, kazniti one koji su prešli na grkokatoličku vjeroispovijest. ${ }^{15}$ Iz odnosa Grkokatoličke i Rimokatoličke crkve prema objektima Srpske pravoslavne crkve u Moslavini moguće je također iščitati i odnos snaga tih dviju crkvi. Jasno je da je Rimokatolička crkva u Hrvatskoj imala monopol nad vjerskim prijelazima i bila u mnogo boljem položaju

15 Temelj za takvo kažnjavanje bile su pojedine okružnice i dopisi. Ministarstvo pravosuđa i bogoštovlja NDH šalje dopis Biskupskim Ordinarijatima NDH 14. srpnja 1941. iz kojeg je vidljivo da se država protivi prijelazima na grkokatoličku vjeroispovijest. Dana 16. srpnja 1941. Crkva odgovara dopisom Ministarstvu pravosuđa i bogoštovlja u kojem ističe da nije potrebno braniti prijelaze na grkokatoličku vjeroispovijest. Već 30. srpnja 1941. Državno ravnateljstvo za gospodarsku ponovu piše okružnicu u kojoj se ponavlja želja hrvatskih vlasti da pravoslavci ne prelaze na grkokatoličku vjeroispovijest osim u onim krajevima gdje već postoje grkokatoličke župe. O svemu ovome vidi više u: Krišto, 2001: 172-202. 
kod pitanja vjerskih prijelaza od Grkokatoličke crkve. Iako su formalno te dvije crkve svaka za sebe imale svoje vodstvo, iz raznih je dopisa lako uočiti da je vladika Šimrak bio u lošijem položaju od nadbiskupa Stepinca, barem što se tiče dobivanja objekata i parohija Srpske pravoslavne crkve, i da je s njim morao pregovarati oko većine objekata Srpske pravoslavne crkve koji su stajali prazni ili poluprazni nakon travnja 1941. dokazujući svoja povijesna prava na te prostore. Činjenica je također da je Rimokatolička crkva u pojedinim naseljima osnovala i prijelazničke nove rimokatoličke župe, kao što je to bio slučaj s Mikleuškom, gdje je broj onih koji su prešli na rimokatoličku vjeroispovijest bio toliki da ih rimokatoličke župe u okolici nisu mogle prihvatiti pod svoje okrilje. Da prijelazi s pravoslavne na rimokatoličku i grkokatoličku vjeroispovijest nisu u većini slučajeva bili iskreni, govori i činjenica koju naglašavaju neki župnici da se bivši pravoslavni žitelji, sada novopečeni rimokatolici, nisu pojavljivali u rimokatoličkoj crkvi ili slavili rimokatoličke blagdane. Stoga možemo zaključiti da se između 1941. i 1945. s pravoslavne na rimokatoličku i grkokatoličku vjeroispovijest konvertiralo zbog specifičnog osjećaja nesigurnosti Srba i straha za fizički opstanak u ekskluzivistički utemeljenoj državi kakva je bila NDH. Osnutkom Hrvatske pravoslavne crkve, smanjivanjem intenziteta ustaških odmazdi i prestankom organiziranoga prisilnog iseljavanja Srba iz NDH brojnost i intenzitet vjerskih prijelaza s pravoslavne na katoličku vjeroispovijest smanjili su se u navedenim i obrađenim župama na zanemarivu razinu.

\section{LITERATURA}

Bunjevac, S. (2005). Izvorni dokumenti OZN-e o biskupu dr. Janku Šimraku i "prekrštavanju «Srba u NDH, Glas koncila, 15/05, 17/05, 18/05, 19/05, 21/05, 22/05, 23/05, 24/05, 23/05, 35/06, 27/05, http://www.pobijeni.info/userfiles/BiskupJankoSimrak.pdf (6. prosinca 2017.).

Dizdar, Z. (2002). Ljudski gubici logora Danica kod Koprivnice 1941. - 1942., Časopis za suvremenu povijest, 34 (2): 377-407.

Đurić, Đ. V. (1991). Prekrštavanje Srba u Nezavisnoj Državi Hrvatskoj: prilozi za istoriju verskog genocida. Beograd: Alfa Zemun.

Jelić-Butić, F. (1978). Ustaše i NDH. Zagreb: SN Liber - Školska knjiga.

Karanović, V. (1981). Moslavački partizanski odred 1941. - 1945. Kutina: Skupština općine - Općinski odbor SUBNOR-a.

Kraljevina Jugoslavija, Opšta državna statistika (1938). Definitivni rezultati popisa stanovništva od 31. marta 1931. godine, knjiga II, Prisutno stanovništvo po veroispovesti. Beograd: Državna štamparija.

Krišto, J. (1998). Katolička crkva i Nezavisna Država Hrvatska 1941. - 1945., knjiga prva druga. Zagreb: Hrvatski institut za povijest. 
Krišto, J. (2001). Sukob simbola: politika vjere i ideologije u Nezavisnoj Državi Hrvatskoj, Zagreb: Nakladni zavod Globus.

Draganović, K. (1975). Opći šematizam katoličke crkve u Jugoslaviji - Cerkev v Jugoslaviji 1974. Zagreb: Biskupska konferencija Jugoslavije.

Požar, P. (1996). Hrvatska pravoslavna crkva u prošlosti i budućnosti. Zagreb: Naklada Pavičić.

Škiljan, F. (2012). Prisilno iseljavanje Srba iz Moslavine 1941. godine, Historijski zbornik, 65 (1): 149-169.

Škiljan, F. (2014). Prevjeravanje Srba na području sjeverozapadne Hrvatske 1941. i 1942. godine, Tokovi istorije, 1: 135 - 173.

Škiljan, F. (2015a). Vjerski prijelazi s pravoslavne na rimokatoličku i grkokatoličku vjeroispovijest na području kotara Križevci u vrijeme NDH, Cris, 17 (1): 97-107.

Škiljan, F. (2015b). Vjerski prijelazi s pravoslavne na rimokatoličku i grkokatoličku vjeroispovijest na području kotareva Pakrac i Daruvar između 1941. i 1945., Zbornik Janković, 1 (1): 101-122.

Škiljan, F. (2015c). Organizirana prisilna iseljavanja Srba iz NDH. Zagreb: Srpsko narodno vijeće.

Škiljan, F. (2016a). Vjerski prijelazi s pravoslavne na rimokatoličku i grkokatoličku vjeroispovijest u Podravini između 1941. i 1945. godine, Podravina, 15 (29): 168-179.

Škiljan, F. (2016b). Vjerski prijelazi s pravoslavne na rimokatoličku vjeroispovijest u NDH (1941. - 1945.) na području arhiđakonata Svetačje (Novska, Nova Gradiška, Oriovac), Kultura polisa, 12 (31): 185-202.

Škiljan, F. (2016c). Vjerski prijelazi na rimokatoličku i grkokatoličku vjeroispovijest na području Varaždina, Međimurja i u Hrvatskom zagorju između 1941. i 1945. Hrvatsko zagorje, časopis za kulturu, 117-135.

Škiljan, F. (2016d). Vjerski prijelazi s pravoslavne na rimokatoličku i grkokatoličku vjeru u vrijeme $\mathrm{NDH}$ na području Bjelovarskog dekanata, Radovi Zavoda za znanstvenoistraživački i umjetnički rad u Bjelovaru, 10: 295-314, doi: https://doi. org/10.21857/90836cdoqy

Škiljan, F. (2017a). Vjerski prijelazi s pravoslavne na rimokatoličku vjeroispovijest na području Vašćanskog arhiđakonata (Virovitica, Slatina, Orahovica, Našice) u vrijeme NDH (1941. - 1945.), Scrinia slavonica, 17: 223-251.

Škiljan, F. (2017b). Prevjeravanja pravoslavnih Srba u Goričkom arhiđakonatu (Karlovac i okolica) između 1941. i 1945. godine, Arhiv, 18 (1-2): 127-145.

Škiljan, F. (2017c). Vjerski prijelazi s pravoslavlja na rimokatoličku vjeru između 1941. i 1945. na području kotara Požega, Radovi Zavoda za znanstveni i umjetnički rad u Požegi, 6: 173-195, doi: https://doi.org/10.21857/ydkx2c3vd9

Tomasevich, J. (2010). Rat i revolucija u Jugoslaviji 1941. - 1945.: okupacija i kolaboracija. Zagreb: EPH Media.

Zatezalo, Đ. (2009). Jadovno - kompleks ustaških logora 1941., knjiga I-II. Beograd: Muzej žrtava genocida. 


\section{ARHIVSKI IZVORI}

NAZ (Nadbiskupijski arhiv u Zagrebu), Nadbiskupski duhovni stol (NDS), 1941., 1942, 1943., Interdijecezalni vjerski odjel (IVO), 1941., 1942.

HDA (Hrvatski državni arhiv), Državno ravnateljstvo za ponovu (DRP), Vjerski odsjek (VO), 1941.

HDA, Ministarstvo pravosuđa i bogoštovlja NDH (MPB NDH), Odjel bogoštovlja (OB), 1941., 1942. 


\title{
Religious Conversions from Orthodoxy to Roman Catholicism and Greek Catholicism in the Archdeaconry of Čazma between 1941 and 1945
}

\author{
Filip Škiljan
}

\section{SUMMARY}

The number of converts from Orthodoxy to Roman Catholicism during WWII has been discussed for years. The earliest cumulative quantification of Orthodox-toCatholic conversions in the NDH (Independent State of Croatia) may be found in a report by Pope Pius XII of 1943, which was written by Archbishop Alojzije Stepinac. Although there are still speculations about the total number of Orthodox converts to Roman Catholic faith in the period of WWII, most controversies today are mainly concerned with the nature and ethics of the doctrinal consistency and political opportunity of the conversion itself.

During the period in between the wars, the Čazma Archdeaconry consisted of several districts: Čazma, Kutina, Ivanić Grad, Grubišno Polje and Garešnica. According to the census of 1931, less than $14 \%$ of the population were Orthodox Christians. The author of the paper researches the conversions form Orthodoxy to Roman Catholicism in the mentioned area during the period between 1941 and 1945. The research is based on the records from archive holdings such as the Archbishop's Clerical Board of the Archbishop's Archive in Zagreb, the Ministry of Justice and the NDH Ministry of Justice and Worship at the Croatian State Archive. Based on the list of names of converted persons, i.e. those who filed an application to convert in the area of 23 parishes in the territory of the Čazma Archdeaconry, the author concludes that no fewer than 3,271 Orthodox Christians filed an application to convert to Roman Catholicism, mainly from April 1941 to April 1942. According to the preserved documents from the Archbishop's Archive in Zagreb and from the Croatian State Archive, the actual number of conversions was even larger; however, no list of names of those who filed an application to convert or of those who underwent conversion is preserved. Such a problem arose in the parish of Mikleuška where people converted collectively, in large numbers. In this paper, the author discusses the types of individual conversions. The largest number of religious conversions were made in the area of Miklueška, where 751 individuals converted. Vicar Đurić from the parish of Kaniška Iva asked the Archbishop's Clerical Board for missionaries to help him teach and convert the Orthodox. He demanded at least six more missionaries, two for the villages of Veliko Vukovje, Malo Vukovje, Gojilo and Rogoža, two for Stupovača, Brinjani, Čaire and Kutinica, and two for Velika Bršljanica, a part of Rogoža and Mala Bršljanica. The missionaries arrived in the winter of 1941/1942. Vicar Đurić compiled a list of converts, 1,372 of them being from the area of the former Orthodox parish of Veliko Vukovje. Due to a large number of converts, there was a plan to set up a new Roman Catholic parish in Narta, in the vicinity of Čazma. As a special aspect of this research, the author observes the conversions to Greek Catholicism (in the Veliki Zdenci and Čazma area) and the reasons why the state authorities did not want the Orthodox to convert to Greek Catholicism. According to a circular issued by the Ministry of Justice and Worship, the Main Ustaša Headquarters and the State Directorate for Economic Regeneration, dated 30 July 1941, it is apparent that the "wish of 
the Croatian government" was that "the Orthodox do not switch the Greek Catholic religion..." The Greek Catholic priests considered that they had the right of ownership over all Orthodox churches in the district of Garešnica because of the existence of their parish in Dišnik. Bishop Janko Šimrak requested that certain churches in Moslavina, among others, the church in Lipovčani, chapels in Marča, and churches in Narta and Veliko Vukovje become part of the Greek Catholic Church. However, most of these churches were provided for by the Roman Catholic Church. The author finally concludes, on the basis of reports from some parishioners, that in most cases, conversion to Roman Catholicism was not honest, that the Serbs were mostly forced to convert to Roman Catholic faith for the sake of preserving their existence and their lives. Following the foundation of the Croatian Orthodox Church in the first half of 1942, the Orthodox generally ceased to attend Roman Catholic masses.

KEY WORDS: religious conversions, Serbs, Second World War, Moslavina, Archdeaconry of Čazma 
